\title{
Occupational Risk Factors for Prostate Cancer: A Meta-analysis
}

REVIEW

\author{
Srmena Krstev ${ }^{1}$, Anders Knutsson ${ }^{2}$ \\ ${ }^{1}$ Serbian Institute of Occupational Health, Belgrade, Serbia, ${ }^{2}$ Department of Health Sciences, Mid Sweden University, Sundsvall, Sweden
}

\begin{abstract}
Prostate cancer is the second most common cancer in men worldwide. There are many occupational factors that have been suggested to cause prostate cancer. Our aim was to evaluate the evidence for causality by a literature review of occupational factors. We searched literature in Medline and SCOPUS from 1966 to June 30, 2015 to identify occupational risk factors for prostate cancer. The following risk factors were selected: farmers/agricultural workers, pesticides - whole group, and separately organophosphate and organochlorine pesticides, carbamates and triazines, cadmium, chromium, cutting fluids, acrylonitrile, rubber manufacturing, whole body vibration, shift work, flight personnel, ionizing radiation, and occupational physical activity. For each factor a literature search was performed and presented as meta-analysis of relative risk and heterogeneity ( $Q$ and $\mathrm{I}^{2}$ index). A total of 168 original studies met the inclusion criteria with 90,688 prostate cancer cases. Significantly increased risks were observed for the following occupational exposures: pesticides (metaRR $=1.15,95 \%$ confidence interval $\left.[C]=1.01-1.32 ; 1^{2}=84 \%\right)$, and specifically group of organochlorine pesticides (meta relative risk $\left[\right.$ metaRR] $=1.08,95 \% \mathrm{Cl}=1.03-1.14 ; \mathrm{I}^{2}=0 \%$ ), chromium (metaRR $=1.19,95 \% \mathrm{Cl}=1.07-1.34 ; \mathrm{I}^{2}=31 \%$ ), shift work (metaRR $=1.25,95 \% \mathrm{Cl}=1.05-1.49 ; \mathrm{I}^{2}=78 \%$ ) and pilots (metaRR $=1.41,95 \% \mathrm{Cl}=1.02-1.94 ; I^{2}=63 \%$ ) and occupational physical activity in cohort studies (metaRR $=0.87,95 \% \mathrm{Cl}=0.81-0.94 ;\left.\right|^{2}=0 \%$ ). The literature review supports a causal association for a few of the previously suggested factors.
\end{abstract}

(J Cancer Prev 2019;24:91-111)

Key Words: Epidemiologic studies, Work-place factors, Exposure assessment, Causal association, Literature search

\section{INTRODUCTION}

Worldwide, prostate cancer is the second most common cancer with estimated age-standardized incidence rate 31.1 , and the fifth leading cause of death from cancers in men (age-standardized mortality rate 7.8) [1]. The highest prostate cancer incidence has been recorded in Australia, New Zealand and North America, and in Western and North Europe, while the lowest incidence is noted in Asia. Partly, this difference in incidence can be explained by routine prostate specific antigen (PSA) testing among older age in more developed countries. There is relatively less variation in death rates, which are higher in less developed than in more developed countries. In general, mortality rates are high in Black population and increase with age [2]. In Europe, the highest incidence rates were estimated in Northern and Western countries, such as Norway (193.2), France (187.5), and Sweden (175.2) [3].

Known risk factors for prostate cancer include older age, heredity and race/ethnicity. Most men diagnosed with prostate cancer were older than 65 years [2]. Studies among brothers, fathers and twins indicated that family history of prostate cancer can increase the risk of developing prostate cancer substantially [4-6]. Recent genetic studies revealed that previously observed highest incidence rates of prostate cancer among African American can be partly explained by biological differences based on tumor markers $[2,7,8]$.

Many various exposures at the work places and work environment have been studied thoroughly such as different

Received February 15, 2019, Revised March 20, 2019, Accepted March 20, 2019

Correspondence to: Srmena Krstev

E-mail: srmena.krstev@gmail.com, ORCID: Srmena Krstev, https://orcid.org/0000-0002-6635-7577

Copyright (C) 2019 Korean Society of Cancer Prevention

(c) This is an Open Access article distributed under the terms of the Creative Commons Attribution Non-Commercial License (http://creativecommons.org/licenses/by-nc/4.0) which permits unrestricted non-commercial use, distribution, and reproduction in any medium, provided the original work is properly cited. 
chemical, physical and psychological and ergonomic risk factors; however, the results are not conclusive. Therefore, the aim of this literature review is to examine the association between work-related exposures and prostate cancer and to assess the evidence for the possible relationship.

\section{MATERIALS AND METHODS}

To identify possible occupational risk factors for prostate cancer we first searched for review and meta-analysis articles published from 1966 to June 30, 2015 in Medline and SCOPUS using the following search terms "occupational risk factors and prostate cancer". A total of 182 articles were found. We excluded articles related to methological problems $(n=9)$, environmental and ecologic factors $(n=15)$, biological mechanism/genetic/ molecular factors $(n=17)$, clinical studies (therapy and diagnosis of prostate cancer) $(n=13)$, reviews published in other language than English $(n=20)$, reviews not mentioning results for prostate cancer $(\mathrm{n}=16)$ and duplicates from Medline and SCOPUS ( $n=13$ ) leaving 72 relevant reviews (Supplementary Fig. $\mathrm{SF} 1)$. In that way we identified numerous potential occupational risk factors for prostate cancers such as: pesticides, farmers and agricultural workers, cadmium, chromium, polycyclic aromatic hydrocarbons (PAH), cutting fluids, diesel fumes, metal fabrication, metal dust, rubber, rubber industry, ionizing radiation, electromagnetic fields, shift work, night work, flight personnel, dyeing/ leather processing, vehicle batteries, whole body vibration (WBV), occupational physical activity, circadian disruption and melatonin secretion, acrylonitrile, sunlight and vitamin D deficiency, dioxins and Agent Orange, zinc, lead, stress and job strains, methyl bromide, perchlorethylene, benzo(a)pyrene, methylene chloride, firefighters, sewage workers and petroleum and gasoline, and perfluorooctanoate and perfluorooctanesulfonate [9-80] .

We defined the inclusion criteria for each factor as occupational exposure associated with prostate cancer reported in at least three reviews and/or meta-analysis based on epidemiologic studies. Thus, the following risk factors were selected: farmers/agricultural workers, pesticides, and separately organophosphate and organochlorine pesticides, carbamates and triazines, cadmium, chromium, cutting fluids, acrylonitrile, rubber manufacturing, WBV, shift work, flight personnel, ionizing radiation, and occupational physical activity.

The next step was to search for original articles for each selected occupational factor. For that purpose, the following search terms were used: prostate cancer, prostatic cancer, farmer, farming, agricultural, agriculture, pesticides, cadmium, chromium, rubber, tire, shiftwork, shift work, nightwork, night work, polycyclic aromatic hydrocarbons, cutting oils, mineral oils, ionizing radiation, flight personnel, pilots, physical activity, and acrylonitrile. For each occupational factor the abstracts were reviewed to assess the relevance of the article. Additional relevant articles referred in each article were also considered and included if appropriate. Results of these searches are presented for each selected occupational exposure in flowcharts (Supplementary Fig. SF2, SF4, SF6, SF8, SF10, SF12, SF14, SF16, SF18, SF20, SF22, SF24, SF26, SF28, SF30, SF32). Selected articles were reviewed in the full text format.

Inclusion criteria for articles were as follows: Articles written in English; Clear objective of the study investigating the relationship between specific workplace exposures and prostate cancer; Longitudinal study design (case/control and cohort); Clear definition of study population; The study with the longest follow-up period if more than one article was published for the same cohort; Appropriate way of exposure assessment (measurements, job exposure matrix (JEM), expert assessment, self-reported); The highest exposure level was used if risk estimates were reported for different exposure categories so that risk in the group with the highest exposure level was compared with the lowest exposure level; The number of exposed cases equal to or greater than five; Diagnosis of prostate cancer based on biopsy and pathohistological results or solely on death certificates, but not on self-report; Participants in cohort studies free of prostate cancer at the start of study; Controls in case-control studies free of any cancers; Results reported as the relative risk estimates (standardized mortality ratio [SMR], standardized incidence ratio [SIR], incidence rate ratio [IRR], or hazard ratio [HR] for cohort studies and odds ratio [OR] for case-control studies) and 95\% confidence intervals (CIs). In some cases, the CIs were not reported, but were calculated based on reported data with the Mid-P exact test [81]; Incidence rates were presented if article reported both mortality and incidence results; Minimum requirement for adjustment for confounding included age. If the publication reported both age-adjusted risk and risks adjusted for multiple variables, the age-adjusted risk was used. If only multivariable adjusted risk had been reported it was used.

Studies of polycyclic aromatic hydrocarbons and prostate cancer were considered and analyzed, but due to the low quality of exposure data were not presented.

For the meta-analysis calculations, the program Stata ver. 11 was used and random effect model. Heterogeneity was expressed as $\mathrm{Q}$ statistics and $\mathrm{I}^{2}$ index. Interpretation of $\mathrm{I}^{2}$ was as follows: very consistent (0\%-24\%); low heterogeneity (25\%-49\%), medium 
heterogeneity (50\%-74\%), and high heterogeneity (75\%-100\%) [82].

\section{RESULTS}

A summary of results obtained for selected occupational risk factors related to prostate cancer are presented on Table 1. Significant results and tables are presented here while non-significant tables (Supplementary Table ST1-10) and all figures (Supplementary Figure SF1-33) are shown in the Supplement.

Among the huge number of "pesticides" in use, in this meta-analysis we decided to include the non-specified pesticide use, as well as exposure to four most frequently used and reported pesticides groups: organochlorine and organophosphate pesticides, carbamates, and triazines. The literature search for the whole group of pesticides (Table 2, Supplementary Fig. SF2) shows that a total of 18 studies were included in meta-analysis, 14 cohort studies and 5 case control studies [83-100]. Significantly increased risk for prostate cancer was found, however, the heterogeneity was large (Table 1, Supplementary Fig. SF3). Separate analysis for cohort and case control studies reported non-significantly increased risks. Heterogeneity was large for cohort studies and low for case-control studies.

On Table 3 and Supplementary Figure SF4, 17 selected studies of "organochlorine" pesticides are presented, 10 cohort and 7 case-control studies [92,101-116]. There is a significantly increased risk for prostate cancer among workers exposed to organochlorine pesticides, study results were homogenous (Table 1, Supplementary Fig. SF5), as was also observed for cohort studies.

Table 1. Meta-analysis summary of the examined risk factors for prostate cancer

\begin{tabular}{|c|c|c|c|c|c|c|c|}
\hline Occupational risk factor & No. of studies & No. of cases & MetaRR & $95 \% \mathrm{CI}$ & $Q$ & $P$-value & $\mathrm{I}^{2}(\%)$ \\
\hline Pesticides & 18 & 3,474 & 1.15 & $1.01-1.32$ & 110 & $<0.001$ & 84 \\
\hline Coh & 13 & 3,067 & 1.13 & $0.97-1.32$ & 96 & $<0.001$ & 86 \\
\hline CC & 5 & 407 & 1.26 & $0.86-1.83$ & 15 & 0.006 & 33 \\
\hline Organochlorines & 17 & 2,730 & 1.08 & $1.03-1.14$ & 43 & 0.49 & 0 \\
\hline Coh & 10 & 1,003 & 1.12 & $1.05-1.19$ & 13 & 0.6 & 0 \\
\hline $\mathrm{CC}$ & 7 & 1,727 & 0.99 & $0.89-1.10$ & 26 & 0.53 & 0 \\
\hline Chromium & 8 & 964 & 1.19 & $1.07-1.34$ & 10 & 0.18 & 31 \\
\hline Shiftwork & 6 & 1,355 & 1.25 & $1.05-1.49$ & 36 & $<0.000$ & 78 \\
\hline Coh & 4 & 861 & 1.14 & $0.98-1.32$ & 11 & 0.052 & 55 \\
\hline $\mathrm{CC}$ & 2 & 494 & 1.50 & $0.91-2.48$ & 21 & $<0.000$ & 90 \\
\hline Flight personnel & 3 & 180 & 1.26 & $0.90-1.76$ & 8.9 & 0.031 & 66 \\
\hline Pilots & 3 & 163 & 1.41 & $1.02-1.94$ & 5.4 & 0.07 & 63 \\
\hline Occupational physical activity & 18 & 3,417 & 0.90 & $0.80-1.02$ & 55 & $<0.000$ & 69 \\
\hline Coh & 10 & 1,684 & 0.87 & $0.80-0.94$ & 8.5 & 0.48 & 0 \\
\hline $\mathrm{CC}$ & 8 & 1,733 & 0.91 & $0.68-1.20$ & 44 & $<0.000$ & 84 \\
\hline Whole body vibration & 10 & 6,224 & 1.03 & $0.98-1.09$ & 66 & $<0.000$ & 77 \\
\hline Coh & 5 & 4,768 & 1.01 & $0.98-1.05$ & 19 & 0.004 & 69 \\
\hline $\mathrm{CC}$ & 5 & 1,456 & 1.31 & $1.00-1.72$ & 47 & $<0.000$ & 83 \\
\hline Farming, farmers & 26 & 66,749 & 0.99 & $0.95-1.02$ & 118 & $<0.001$ & 79 \\
\hline Coh & 15 & 65,448 & 0.97 & $0.94-1.00$ & 90 & $<0.001$ & 58 \\
\hline $\mathrm{CC}$ & 11 & 1,301 & 1.04 & $0.90-1.21$ & 21 & 0.021 & 33 \\
\hline Organophosphates & 7 & 1,350 & 0.98 & $0.87-1.11$ & 8 & 0.44 & 0 \\
\hline Coh & 4 & 901 & 0.97 & $0.82-1.14$ & 1.1 & 0.77 & 0 \\
\hline $\mathrm{CC}$ & 3 & 449 & 0.99 & $0.78-1.25$ & 7 & 0.15 & 41 \\
\hline Carbamates & 5 & 520 & 1.05 & $0.89-1.24$ & 8 & 0.22 & 27 \\
\hline Triazines & 4 & 471 & 1.02 & $0.92-1.14$ & 7 & 0.13 & 45 \\
\hline Cadmium & 7 & 71 & 1.12 & $0.82-1.53$ & 6 & 0.42 & 0 \\
\hline Cutting fluids & 8 & 446 & 1.03 & $0.92-1.16$ & 9 & 0.42 & 0 \\
\hline Coh & 5 & 285 & 1.03 & $0.88-1.21$ & 7 & 0.29 & 18 \\
\hline $\mathrm{CC}$ & 3 & 161 & 0.89 & $0.66-1.21$ & 0.9 & 0.64 & 9 \\
\hline Acrylonitrile & 4 & 54 & 0.93 & $0.71-1.21$ & 0.41 & 0.94 & 0 \\
\hline Rubber manufacturing & 15 & 923 & 0.98 & $0.87-1.09$ & 0.33 & 0.005 & 55 \\
\hline Ionizing radiation & 9 & 1,624 & 1.07 & $0.97-1.17$ & 20 & 0.009 & 61 \\
\hline
\end{tabular}

MetaRR, meta relative risk; CI, confidence interval; Coh, cohort study; CC, case control study. 
Table 2. Description of studies examining the association between pesticides and prostate cancer

\begin{tabular}{|c|c|c|c|c|c|c|c|}
\hline Reference (first author) & Design & Country & Exposure & No. of cases & Measure of risk & Risk & $95 \% \mathrm{CI}$ \\
\hline Alberghini (1991) [83] & Coh & Italy & Pesticide users & 19 & SMR & 0.59 & $0.28-1.24$ \\
\hline Beard (2003) [84] & Coh & Australia & Laboratory staff & 16 & SIR & 1.05 & $0.46-2.40$ \\
\hline Boers (2005) [85] & Coh & The Netherlands & General population & 32 & $\mathrm{RR}$ & 0.64 & $0.41-1.00$ \\
\hline Cantor (1999) [86] & Coh & USA & Pesticide users & 140 & SMR & 1.40 & $0.87-2.25$ \\
\hline Dich (1998) [87] & Coh & Sweden & Pesticide users & 401 & SIR & 1.13 & $1.02-1.25$ \\
\hline Ewings (1996) [88] & $\mathrm{CC}$ & Great Britain & Pesticide users & 97 & OR & 0.68 & $0.44-1.05$ \\
\hline Figà-Talamanca (1993) [89] & Coh & Italy & Pesticide users & 6 & SMR & 1.00 & $0.37-2.73$ \\
\hline Fleming (1999) [90] & $\mathrm{Coh}$ & USA & Pesticide users & 353 & $\operatorname{SIR}$ & 1.91 & $1.72-2.12$ \\
\hline Fleming (2003) [91] & Coh & USA & Pesticide users & 22 & $\mathrm{RR}$ & 1.30 & $0.80-2.11$ \\
\hline Fritschi (2007) [92] & $\mathrm{CC}$ & Australia & Pesticide users & 52 & OR & 1.02 & $0.69-1.51$ \\
\hline Frost (2011) [93] & Coh & Great Britain & Pesticide users & 205 & SIR & 1.07 & $0.93-1.23$ \\
\hline \multirow[t]{2}{*}{ Koutros (2010) [94] } & \multirow[t]{2}{*}{ Coh } & \multirow[t]{2}{*}{ USA } & \multirow{2}{*}{$\begin{array}{l}\text { Private users, } \\
\text { commercial users }\end{array}$} & 1,719 & SIR & 1.19 & $1.14-1.24$ \\
\hline & & & & 73 & SIR & 1.28 & $1.00-1.64$ \\
\hline Meyer (2007) [95] & $\mathrm{CC}$ & USA & Pesticide users & 177 & OR & 1.60 & $1.20-2.13$ \\
\hline Sperati (1999) [96] & Coh & Italy & Pesticide users & 5 & SMR & 0.80 & $0.26-2.46$ \\
\hline Subahir (2009) [97] & CC & Malaysia & Pesticide exposure & 9 & OR & 2.40 & $1.11-5.19$ \\
\hline Torchio (1994) [98] & Coh & Italy & Pesticide users & 66 & SMR & 0.96 & $0.74-1.25$ \\
\hline van der Gulden (1995) [99] & $\mathrm{CC}$ & The Netherlands & Pesticide users & 72 & OR & 1.47 & $0.88-2.46$ \\
\hline Zhong (1996) [100] & Coh & Island & Pesticide users & 10 & SIR & 0.70 & $0.33-1.48$ \\
\hline
\end{tabular}

CI, confidence interval; Coh, cohort study; CC, case control study; SMR, standardized mortality ratio; SIR, standardized incidence ratio; RR, relative risk; OR, odds ratio.

A total of eight cohort studies were selected for studying association between "chromium" exposure and prostate cancer (Table 4, Supplementary Fig. SF6) [117-124]. A significant excess of meta-risk for prostate cancer was observed with a low heterogeneity (Table 1, Supplementary Fig. SF7).

Search for the association between "shift work" and prostate cancer revealed six studies, three cohort and three case-control studies (Table 5, Supplementary Fig. SF8) [125-130]. We observed significantly elevated risk associated with prostate cancer (Table 1. Supplementary Fig. SF9), heterogeneity was large. Separate analysis for cohort and case-control studies revealed positive non-significant associations. A separate literature search for "flight personnel" (pilots and cabin crew) revealed three cohort studies (Table 5, Supplementary Fig. SF10) [131-133]. Our meta-analysis among flight personnel revealed non-significantly increased risk estimate for prostate cancer. When only pilots were included in the analysis, the risk estimate was significantly elevated; however, the heterogeneity was still large (Table 1, Supplementary Fig. SF11).

A total of 18 studies were included in the meta-analysis of "occupational physical activity", 10 cohort and 8 case-control studies (Table 6, Supplementary Fig. SF12) [134-151]. Our meta-analysis revealed negative association with higher workplace physical strain, not statistically significant (Table 1 , Supplementary Fig. SF13). Similar results were obtained for separate analysis of case-control studies; however, in cohort studies reduced risk was significant, and studies were homogeneous.

Non-significant results are presented in the Supplement (Supplementary Table ST1-ST10, Supplementary Fig. SF15, SF17, SF19, SF21, SF23, SF25, SF27, SF29, SF31, SF33) [85,88,92,95,101,108,111,147,152-227].

\section{DISCUSSION}

A total of 168 original studies that met the inclusion criteria were considered in this meta-analysis, with 90,688 prostate cancer cases. Meta-analyzes of selected work-related risk factors for prostate cancer revealed significant excess in risk for pesticides (without specification of the type of pesticides), and specifically organochlorine pesticides, chromium and shift work. In addition, increased risk for pilots was observed. Physical activity at work was associated with a reduced risk; it was statistically significant only in cohort studies.

\section{Pesticides}

Pesticides were already in use in the mid-1800s, most commonly Paris Green produced of copper and arsenic trioxide [228], replaced progressively in the late 1800 s by lead arsenate. In the 1960s the use of lead arsenate was reduced since its adverse health effects were recognized, but it was not banned as late as in 1988, and large areas of agricultural land in the United States are 
Table 3. Description of studies examining the association between organochlorine pesticides and prostate cancer

\begin{tabular}{|c|c|c|c|c|c|c|c|}
\hline Reference (first author) & Design & Country & Exposure & No. of cases & Measure of risk & Risk & $95 \% \mathrm{CI}$ \\
\hline Alavanja (2003) [101] & Coh & USA & Organochlorine pesticides & 47 & OR & 1.39 & $0.99-1.95$ \\
\hline \multirow[t]{7}{*}{ Aronson (2010) [102] } & $\mathrm{CC}$ & Canada & DDE & 24 & OR & 0.73 & $0.38-1.40$ \\
\hline & & & DDT & 26 & OR & 1.05 & $0.55-2.00$ \\
\hline & & & Trans-nonachlor & 22 & OR & 0.83 & $0.42-1.64$ \\
\hline & & & Oxychlordane & 24 & OR & 0.95 & $0.49-1.84$ \\
\hline & & & Hexachlorobenzene & 29 & OR & 1.27 & $0.66-2.44$ \\
\hline & & & Mirex & 24 & OR & 0.58 & $0.32-1.05$ \\
\hline & & & $\beta$-hexachlorocyclo-hexane & 29 & OR & 1.08 & $0.57-2.05$ \\
\hline Asp (1994) [103] & Coh & Finland & Chlorophenoxy & 6 & SIR & 0.37 & $0.14-0.98$ \\
\hline Burns (2001) [104] & Coh & USA & 2,4-D & 7 & SMR & 1.34 & $0.54-3.33$ \\
\hline Coggon (2015) [105] & Coh & Great Britain & Fenoxy & 129 & SMR & 1.14 & $0.92-1.41$ \\
\hline Fritschi (2007) [92] & $\mathrm{CC}$ & Australia & Organochlorine pesticides & 36 & OR & 0.76 & $0.33-1,75$ \\
\hline Hardell (2006) [106] & $\mathrm{CC}$ & Sweden & Chlordane & 15 & OR & 1.50 & $0.50-4.50$ \\
\hline Kogevinas (1997) [107] & Coh & 9 countries & Phenoxy, chlorophenol & 68 & SMR & 1.10 & $0.85-1.42$ \\
\hline \multirow[t]{7}{*}{ Koutros (2013) [108] } & Coh & USA & Aldrin & 64 & $\mathrm{RR}$ & 1.25 & $0.97-1.61$ \\
\hline & & & Chlordane & 58 & $\mathrm{RR}$ & 1.02 & $0.78-1.33$ \\
\hline & & & DDT & 95 & $\mathrm{RR}$ & 1.18 & $0.95-1.47$ \\
\hline & & & Dieldrin & 18 & $\mathrm{RR}$ & 0.93 & $0.58-1.49$ \\
\hline & & & Heptachlor & 44 & $\mathrm{RR}$ & 1.05 & $0.78-1.41$ \\
\hline & & & Lindane & 39 & $\mathrm{RR}$ & 1.16 & $0.84-1.60$ \\
\hline & & & Toxaphene & 38 & $\mathrm{RR}$ & 0.97 & $0.70-1.34$ \\
\hline Lee (2004) [109] & $\mathrm{Coh}$ & USA & Alachlor & 325 & SIR & 1.16 & $1.04-1.29$ \\
\hline Lynge (1998) [110] & Coh & Denmark & Phenoxy & 15 & SIR & 1.00 & $0.60-1.67$ \\
\hline \multirow[t]{5}{*}{ Mills (2003) [111] } & $\mathrm{CC}$ & USA & Chlorothalonil & 135 & OR & 1.06 & $0.71-1.58$ \\
\hline & & & Dichloropropene & 131 & OR & 1.00 & $0.68-1.47$ \\
\hline & & & Dicofol & 131 & OR & 0.94 & $0.65-1.36$ \\
\hline & & & Heptachlor & 140 & OR & 1.35 & $0.91-2.00$ \\
\hline & & & Lindane & 129 & OR & 1.32 & $0.88-1.98$ \\
\hline Mozzachio (2008) [112] & Coh & USA & Chlorothalonil & 23 & $\mathrm{RR}$ & 0.79 & $0.52-1.20$ \\
\hline Multigner (2010) [113] & $\mathrm{CC}$ & $\begin{array}{l}\text { French West } \\
\text { Indies }\end{array}$ & Chlordecone & 161 & OR & 1.27 & $0.93-1.73$ \\
\hline \multirow[t]{4}{*}{ Ritchie (2003) [114] } & $\mathrm{CC}$ & USA & Dialdrin & 58 & OR & 0.28 & $0.09-0.87$ \\
\hline & & & Heptachlor & 58 & OR & 0.33 & $0.10-1.09$ \\
\hline & & & Trans-nonachlor & 58 & OR & 1.18 & $0.45-3.09$ \\
\hline & & & Oxychlordane & 58 & OR & 1.23 & $0.42-3.60$ \\
\hline Samanic (2006) [115] & Coh & USA & Dicamba & 67 & $\mathrm{RR}$ & 1.08 & $0.81-1.44$ \\
\hline \multirow[t]{9}{*}{ Sawada (2010) [116] } & $\mathrm{CC}$ & Japan & $o, p^{\prime}-\mathrm{DDT}$ & 47 & OR & 1.07 & $0.59-1.94$ \\
\hline & & & p,p'-DDT & 46 & OR & 1.02 & $0.57-1.83$ \\
\hline & & & DDE & 53 & OR & 0.96 & $0.58-1.59$ \\
\hline & & & Trans-nonachlor & 52 & OR & 0.83 & $0.43-1.60$ \\
\hline & & & Cis-nonachlor & 51 & OR & 0.84 & $0.45-1.57$ \\
\hline & & & Oxychlordane & 49 & OR & 0.77 & $0.39-1.52$ \\
\hline & & & $\mathrm{HCB}$ & 42 & OR & 0.49 & $0.21-1.14$ \\
\hline & & & Mirex & 56 & OR & 0.95 & $0.54-1.67$ \\
\hline & & & $\beta-\mathrm{HCH}$ & 43 & OR & 0.78 & $0.46-1.32$ \\
\hline
\end{tabular}

CI, confidence interval; Coh, cohort study; CC, case control study; OR, odds ratio; SIR, standardized incidence ratio; SMR, standardized mortality ratio; $\mathrm{RR}$, relative risk.

still contaminated by lead arsenate [228]. As a proven carcinogen, exposure to arsenic may have contributed to cancers in workers' cohorts exposed before the 1980s. Since then, there have been many different pesticides on the market. This make a problem in the assessment of hazardous effects of pesticides as individuals were exposed to many various pesticides and different chemical substances have been used over time.

Pesticides are used to control pests, such as molds, insects and unwanted plants [21] and are commonly grouped based on the target of their effect, such as herbicides, fungicides and insecticides. Pesticides may also be grouped based on their chemical composition: most frequently used are organochlorine 
Table 4. Description of studies examining the association between chromium and prostate cancer

\begin{tabular}{|c|c|c|c|c|c|c|c|}
\hline Reference (first author) & Design & Country & Exposure & No. of cases & Measure of risk & Risk & $95 \% \mathrm{CI}$ \\
\hline Axelsson (1980) [117] & Coh & Sweden & Ferrochromium workers & 10 & SMR & 1.10 & $0.68-1.78$ \\
\hline Gibb (2000) [118] & Coh & USA & Chromium chemical production & 16 & SMR & 1.22 & $1.00-1.49$ \\
\hline Huvinen (2013) [119] & Coh & Finland & Ferrochromium, stainless steel & 89 & SIR & 1.31 & $1.05-1.63$ \\
\hline Jakobsson (1997) [120] & Coh & Sweden & Grinding stainless steel & 36 & SIR & 1.70 & $1.20-2.41$ \\
\hline Knutsson (2000) [121] & Coh & Sweden & Concrete & 769 & SIR & 1.08 & $1.01-1.15$ \\
\hline Langård (1990) [122] & Coh & Norway & Ferrochromium & 12 & SMR & 1.56 & $0.68-3.58$ \\
\hline Rafnsson (1997) [123] & Coh & Island & Masons & 25 & SIR & 1.04 & $0.67-1.61$ \\
\hline Sorahan (2000) [124] & Coh & Great Britain & Chrome platers & 7 & SMR & 1.06 & $0.43-2.61$ \\
\hline
\end{tabular}

CI, confidence interval; Coh, cohort study; SMR, standardized mortality ratio; SIR, standardized incidence ratio.

Table 5. Description of studies examining the association between shift work and flight personnel, and prostate cancer

\begin{tabular}{|c|c|c|c|c|c|c|c|}
\hline References (first author) & Design & Country & Exposure & $\begin{array}{c}\text { No. } \\
\text { of cases }\end{array}$ & $\begin{array}{c}\text { Measure } \\
\text { of risk }\end{array}$ & Risk & $95 \% \mathrm{CI}$ \\
\hline \multicolumn{8}{|l|}{ Shift work } \\
\hline Conlon (2007) [125] & $\mathrm{CC}$ & Canada & Rotating shift & 369 & OR & 1.19 & $1.00-1.42$ \\
\hline \multirow[t]{3}{*}{ Gapstur (2014) [126] } & Coh & USA & Rotating shift & 268 & $\mathrm{RR}$ & 1.13 & $1.00-1.28$ \\
\hline & & & Permanent afternoon/evening & 55 & $\mathrm{RR}$ & 1.35 & $1.04-1.75$ \\
\hline & & & Permanent night & 16 & $\mathrm{RR}$ & 0.78 & $0.47-1.29$ \\
\hline Kubo (2006) [127] & Coh & Japan & Rotating shift & 7 & $\mathrm{RR}$ & 3.0 & $1.20-7.30$ \\
\hline \multirow[t]{2}{*}{ Papantoniou (2015) [128] } & $\mathrm{CC}$ & Spain & Permanent night & 156 & OR & 1.10 & $0.86-1.41$ \\
\hline & & & Rotating night shift & 206 & OR & 1.17 & $0.93-1.47$ \\
\hline Parent (2012) [129] & $\mathrm{CC}$ & Canada & Night shift & 132 & OR & 2.77 & $1.96-3.91$ \\
\hline Yong (2014) [130] & Coh & Germany & Rotating shift including night & 146 & $\mathrm{RR}$ & 0.95 & $0.76-1.19$ \\
\hline \multicolumn{8}{|l|}{ Flight personel } \\
\hline Band (1996) [131] & $\mathrm{Coh}$ & Canada & Pilots & 34 & SIR & 1.87 & $1.38-2.53$ \\
\hline Irvine (1999) [132] & Coh & Great Britain & Pilots & 15 & SMR & 1.11 & $0.62-1.99$ \\
\hline \multirow[t]{2}{*}{ Hammer (2014) [133] } & Coh & 9 countries in & Pilots & 114 & SMR & 1.23 & $0.98-1.54$ \\
\hline & & Europe and USA & Cabin crew & 17 & SMR & 0.75 & $0.40-1.41$ \\
\hline
\end{tabular}

CI, confidence interval; CC, case control study; Coh, cohort study; OR, odds ratio; RR, relative risk; SIR, standardized incidence ratio; SMR, standardized mortality ratio.

pesticides, organophosphorus pesticides, carbamates and triazines.

There have been concerns that pesticide exposure can cause cancer, however, International Agency for Research on Cancer (IARC) [229] concluded in 1991 that there is only a limited evidence to support its carcinogenicity (Group 2B). Since then, numerous studies investigated carcinogenic potential of pesticides among farmers, other agricultural workers, persons who are occupationally spreading pesticides and workers in the industrial manufacturing of pesticides. The most valuable data came from the Agricultural Health Study (AHS) that still follows the pesticide cohort of almost 90,000 participants since 1993 [94].

Several mechanisms have been proposed to explain cancer development due to pesticides. Most pesticides are not mutagenic; however, they may contain endocrine disruptors that act by either blocking or stimulating hormonal receptors and lead to an increase of testosterone. Evidence from epidemiologic studies however, could not prove with certainty that exposure to endocrine disruptors or circulating levels of endogenous androgens are associated with increased risk of prostate cancers [230]. Furthermore, animal and tissue studies have shown that some pesticides, e.g., carbamates can induce chromosomal damage [231-233]. Pesticides can also cause oxidative stress in the cells that forms reactive oxidative radicals which can damage the cells [234].

Studies of the AHS cohort have reported that there is an interaction between exposure to the herbicide and the individual genes [235]. Exposure to fonofos only is not sufficient to increase the risk of prostate cancer, but the interaction with the base excision repair (BER) genes, a mechanism which helps to repair damaged DNA, can increase the risk of prostate cancer in exposed workers. It is also reported that heredity may interact with 
Table 6. Description of studies that examined the relationship between physical activity and prostate cancer

\begin{tabular}{lllcccc}
\hline Reference (first author) & Design & Country & No. of cases & Measure of risk & Risk & $95 \%$ CI \\
\hline Bairati (2000) [134] & CC & Canada & 8 & OR & 0.20 & $0.10-0.40$ \\
Clarke (2000) [135] & Coh & USA & 17 & SMR & 0.79 & $0.46-1.36$ \\
Doolan (2014) [136] & CC & Australia & 494 & OR & 1.19 & $0.97-1.46$ \\
Friedenreich (2004) [137] & CC & Canada & 255 & OR & 0.90 & $0.66-1.23$ \\
Grotta (2015) [138] & Coh & Sweden & 107 & HR & 0.85 & $0.67-1.08$ \\
Hartman (1998) [139] & Coh & USA & 28 & RR & 1.20 & $0.74-1.95$ \\
Hrafnkelsdóttir (2015) [140] & Coh & Island & 450 & HR & 0.84 & $0.74-0.95$ \\
Lacey (2001) [141] & CC & China & 39 & OR & 2.9 & $1.30-6.47$ \\
Le Marchand (1991) [142] & CC & USA & 37 & OR & 0.80 & $0.50-1.28$ \\
Lund Håheim (2006) [143] & Coh & Norway & 507 & RR & 0.86 & $0.53-1.40$ \\
Lund Nilsen (2000)[144] & Coh & Sweden & 116 & RR & 1.04 & $0.82-1.32$ \\
Orsini (2009) [145] & Coh & Sweden & 111 & RR & 0.72 & $0.58-0.89$ \\
Pierotti (2005) [146] & CC & Italy & 386 & OR & 0.75 & $0.61-0.92$ \\
Sass-Kortsak (2007) [147] & CC & Canada & 205 & OR & 1.33 & $1.02-1.73$ \\
Severson (1989) [148] & Coh & USA & 169 & RR & 1.05 & $0.73-1.51$ \\
Thune (1994) [149] & Coh & Norway & 25 & RR & 0.81 & $0.50-1.31$ \\
Wiklund (2008) [150] & CC & Sweden & 309 & OR & 0.84 & $0.66-1.07$ \\
Zeegers (2005) [151] & Coh & The Netherlands & 154 & RR & 0.91 & $0.70-1.18$ \\
\hline
\end{tabular}

CI, confidence interval; CC, case control study; Coh, cohort study; OR, odds ratio; SMR, standardized mortality ratio; HR, hazard ratio; RR, relative risk.

exposure to pesticide [101]. People who have both a family history of prostate cancer and exposure to pesticides have a significantly elevated risk of prostate cancer, which was proven for carbamates, fonofos, chlorpyrifos, and phorate.

There is also evidence that pesticide exposure can lead to an increased aggressiveness of the cancer. The study of Koutros et al. [108] demonstrated that some pesticides, such as fonofos, malathion, and terbufos may stimulate the development of aggressive forms of prostate cancer.

Our meta-analysis showed a statistically significant excess risk of prostate cancer of 1.15 ( $95 \% \mathrm{CI}=1.01-1.32$ ), with a high degree of heterogeneity. Our risk estimate was lower than in the meta-analysis of Van Maele-Fabry and Willems [27], which included 22 cohort and case-control studies published between 1986 and 2003 (meta rate ratio $=1.24 ; 95 \% \mathrm{CI}=1.06-1.45$ ). The update of the AHS by Koutros et al. [94] found that both private and commercial pesticide applicators had an increased risk of prostate cancer $(\mathrm{SIR}=1.19 ; 95 \% \mathrm{CI}=1.14-1.25$ and $\mathrm{SIR}=1.28$; $95 \% \mathrm{CI}=1.00-1.61$, respectively). On the other hand, the meta-analysis by Ragin et al. [11] based on four case-control studies (one unpublished) reported statistically significant decreased risk for pesticide exposure (metaRR $=0.68 ; 95 \% \mathrm{CI}=$ 0.49-0.96). A meta-analysis of 18 cohort studies among workers manufacturing pesticides by Van Maele-Fabry et al. [25] reported a significant increase in risk (metaRR $=1.28 ; 95 \% \mathrm{CI}=1.05-1.58$ ). These inconsistent results can probably be explained by different exposure patterns both with respect to the type of pesticide and the quantities of pesticides to which an individual user is exposed.

\section{Organochlorine pesticides}

Separate analysis for exposure to organochlorine pesticides was associated with a significantly elevated risk of prostate cancer (metaRR $=1.08 ; 95 \% \mathrm{CI}=1.03-1.14)$, and study results were consistent. Separate analysis of cohort studies showed the similar results (metaRR $=1.12 ; 95 \% \mathrm{CI}=1.05-1.19$ ). Two studies included in our meta-analysis had the opposite results: Alavanja et al. [101] also reported an increased risk $(\mathrm{RR}=1.39 ; 95 \% \mathrm{CI}=$ 0.99-1.95), while Fritschi et al. [92] reported decreased risk for organochlorine pesticides in a study from Australia $(R R=0.76$; 95\% CI $=0.33-1.75$ ).

The highest risk estimates for specific organochlorine pesticides were estimated for chlordane $(R R=1.50)$ in a Swedish study [106], heptachlor ( $R R=1.35)$, 2,4-dichlorophenoxyacetic acid (2,4-D) $(R R=1.34)$ and lindane $(R R=1.32)$ in the USA studies [104,111]. In a study of chlordecone [113] a dose-response relationship was found, as the risk of prostate cancer increased gradually from 1.0 to 1.33 with the increase in cumulative exposure index in quartiles and increase in plasma concentrations of chlordecone, strengthening the evidence for a causal relationship.

A problem in many studies examining specific pesticides is 
commonly self-reported exposure, different exposures patterns and the quantities of used pesticides, and multiple exposures to different pesticides which can interfere with each other. A confounding problem may occur if these various types of pesticides are risk factors for prostate cancer.

In recent decades, the use of pesticides has decreased due to the ban of the pesticide use, such as in Sweden [236] where the most frequent use is in the industry, mostly for impregnation of wood [237]. However, the legislation is not uniform worldwide. For example, atrazine has been banned in Sweden since 1989 and in Europe since 2004, but it is still one of the most commonly used herbicides in the USA and Australia.

Our results and previous review articles provide some support that pesticides may increase the risk of prostate cancer although the increase in risk was small. It is however difficult to indicate which specific pesticide is responsible for the increased risk.

\section{Chromium}

Workers engaged in the manufacturing or handling stainless steel are exposed to chromium in varying degrees. As early as in the 1980s chromium was classified as carcinogen with respect to lung cancer [238], and this applies only to hexavalent chromium and not to trivalent or metallic chromium.

Our results revealed a small but significant increase in prostate cancer risk for chromium exposure (metaRR $=1.19$; $95 \% \mathrm{CI}=$ 1.07-1.34), and study results were consistent. This is similar with the results reported by Cole and Rodu [58] in its meta-analysis of 21 studies who also reported a slight but significant excess in risk among workers exposed to chromium (SMR $=114 ; 95 \% \mathrm{CI}=$ 100-129).

We included eight, all incidence studies in our meta-analysis. The highest risk estimates were reported in a Swedish study [120] which included workers who cut and polished stainless steel and were exposed to high concentration of airborne chromium ranging $70-730 \mu \mathrm{g} / \mathrm{m}^{3}$. Three studies examined workers in the ferrochrome production [117,119,122], and risk estimates varied between 1.10 and 1.56. In the study by Huvinen and Pukkala [119], the average airborne concentration of hexavalent chromium was $6.6 \mu \mathrm{g} / \mathrm{m}^{3}$, and in the study by Langård et al. [122] it varied between 10 to $300 \mu \mathrm{g} / \mathrm{m}^{3}$. One study examined workers in chrome production [118], where the measured airborne concentration of hexavalent chromium was on average $9 \mu \mathrm{g} / \mathrm{m}^{3}$, reporting increased risk of 1.22 , with a borderline significance.

Two studies investigated the cancers in masons and concrete workers dealing with cement that contained chromates $[121,123]$. These studies reported the lowest risk estimates of
1.04 and 1.08, respectively. In the Icelandic study [123] of masons, chromium concentration in the cement was in the range 5.8-9.4 $\mathrm{mg} / \mathrm{kg}$, while airborne concentrations of total chromium (both trivalent and hexavalent) were $3-8 \mu \mathrm{g} / \mathrm{m}^{3}$. The personal exposure measurements in urine showed that on Monday levels of chromium were $0.0084 \mu \mathrm{mol} / \mathrm{L}$ and on Thursday $0.0367 \mu \mathrm{mol} / \mathrm{L}$, indicating a significant chromium uptake during the working days.

Exposure to chromium in all included studies was associated with other exposures. In the manufacture of ferrochromium workers were also exposed to nickel, zinc, molybdenum, and polycyclic aromatic hydrocarbons. None of these exposures, however, were linked to prostate cancer. Handling cement generates a dust which besides chromium contains quartz, a carcinogen with respect to lung cancer, but not to prostate cancer. The strength of included studies is that exposure assessment was based on the chromium measurements at workplaces. However, in some cases information on specific exposure to hexavalent chromium was missing.

Our results provide moderate evidence that chromium exposure increases the risk of prostate cancer.

\section{Shift work}

Shift work as a possible cause of prostate cancer has been reviewed thoroughly, but results were inconclusive [47-55]. Several mechanisms are proposed to explain the association of prostate cancer and shift workers. Sleep deprivation affects various endocrine mechanisms, including immune system which in turn can increase the risk of cancer development [239]; however, this was not documented in a cohort of 32,141 persons from the USA [240]. Second hypothesis states that a production of melatonin can be reduced due to a lower exposure to light at night and may stimulate cancer cell growth, which has been proved in animal experiments. An Icelandic study documented that a reduced amount of a melatonin metabolite in urine was associated with increased risk of advanced or lethal prostate cancer in older men [241], however, more studies are needed in younger men. There is also a hypothesis that circadian rhythm affects hormone secretion, including sex hormones, which in turn affects the appearance and growth of cancer cells of prostate. This was supported by a Spanish case-control study which found that night shift workers had higher levels of androgens than day workers [128]. Genetic studies have been also published searching for genetic polymorphism of the clock genes associate with prostate cancer [239,242]. However, the results are inconsistent. 
Our meta-analysis demonstrated a significant association between exposure to shift work and prostate cancer $(R R=1.25$; $95 \% \mathrm{CI}=1.05-1.49)$. The degree of heterogeneity was high, which might be caused by exposure assessments as there is no uniform definition of shift work. Shift work is usually considered as work other than day work that is defined as work between 6 a.m. to 6 p.m. (06:00-18:00). Therefore, permanent night work is defined as shift work. The study included in our meta-analysis that mainly contributed to heterogeneity was published by Parent et al. [129] (calculation not presented). Five studies defined shift work as a night shift that is a part of the shift schedule, while study by Gapstur et al. [126] reported a subgroup of permanent afternoon-evening shift. When this study was excluded, the results of meta-analysis differed only marginally.

Our results are in line with the results of a meta-analysis by Rao et al. [243], which included eight studies ( $R R=1.24 ; 95 \% \mathrm{CI}=$ 1.05-1.46), all six studies from our meta-analysis and in addition studies by Kubo et al. [244] and Schwartzbaum et al. [245]. The former study reported only 4 exposed cases and the later had inadequate exposure assessment, so they were excluded from our meta-analysis.

A review article by Sigurdardottir et al. [246] included 16 studies investigating the relationship between circadian rhythms sleep disorder and the risk of prostate cancer. Studies among flight personnel were considered as well. In 15 studies a positive association was reported and 10 were statistically significant. Three studies in this review examined the relationship between exposure duration (measured as the number of years of night shift work) and prostate cancer risk $[125,128,129]$ and showed a U-shape with the highest risk estimates for short and long duration of exposure. The studies of Conlon et al. [125] and Papantoniou et al.128 had similar risk estimates and shapes, while the study of Parent et al. [129] had a much higher risk estimates for all three intervals of exposure. Categorization of exposure time, however, differs between the three studies; therefore, the results are not entirely comparable.

In summary, there is the evidence from our and previous meta-analyses that shift work including night work can increases the risk of prostate cancer. A weakness of studies is assessment of exposure, as various work schedules were used in the different studies. Moreover, there are only a few reports on the dose-response relationship, and their results are difficult to interpret. There are several biological mechanisms that could explain this relationship, but the evidence of the various stages in the causal chain is not clear enough and can be assessed as "possible" association.

\section{Flight personnel}

A relatively large number of studies have examined a cancer risk among flight personnel. A flight personnel is commonly considered as a proxy for circadian rhythm disorder, as they often fly over many time zones. However, they are also exposed to ionizing cosmic radiation, which is carcinogenic as well. Therefore, an increased risk of cancer can be caused by multiple exposures.

The European Study of Cancer Risks among the Airline Personnel (ESCAPE), a collaboration between researchers from different European countries studied prostate cancer risk among the air personnel. Initially, nine national cohorts from Denmark, Finland, Germany, Greece, Iceland, Italy, Norway, Sweden, and Great Britain were included [247]. Later, a flight personnel from the USA was added [133]. The ESCAPE included studies of national populations [248-252], but also a study that pooled the Nordic countries' cohorts [253]. Results of the nine European countries revealed that SMR of prostate cancer was $0.94(95 \% \mathrm{CI}=$ 0.71-1.26). The latest report from ESCAPE by Hammer et al. [133] presenting results from 10 countries, showed the slight excess of overall risk of prostate cancer (SMR $=1.09 ; 95 \% \mathrm{CI}=0.35-2.68$ ) which was more pronounced among pilots in separate analysis of pilots and cabin crew (SMR $=1.23 ; 95 \% \mathrm{CI}=0.98-1.53)$. The authors speculated that the differences in risks of prostate cancer between the pilots and cabin crew could be due to differences in sleeping patterns and light exposure, but this was not investigated in more details.

We obtained a non-significant increase in risk of prostate cancer for flight personnel ( $m e t a R R=1.26 ; 95 \% \mathrm{CI}=0.90-1.76$ ); excess of risk was statistically significant for pilots only (metaRR = 1.41; $95 \% \mathrm{CI}=1.02-1.94$ ). This was similar as the results from ESCAPE. In our meta-analysis, we did not include any publication of individual country or region that was a part of the ESCAPE, but only the results from 10 countries as a part of ESCAPE [133].

The proposed mechanism for increased prostate cancer risk is that long distance flights over several time zones can induce circadian rhythm disorder. The ESCAPE study did not separately report excess risk among flight personnel that were crossing time zones. Therefore, some other risk factors could also play a role in an increased risk of specific cancers. In the Nordic study on prostate cancer risk among pilots, different duration of flights was considered [253]. Time spent on long-distance flights was measured as the "block hours", which was the sum of the time from the departure gate to the arrival gate. It was observed that the relative risk of prostate cancer in pilots older than 60 years of 
age increased with the number of block hours. Relative risk of prostate cancer was 3.88 (95\% CI $=1.26-11.90)$ for pilots with more than 10,000 block hours compared to the pilots with $\leq 4,999$ block hours. This study, however, did not perform separate analysis for the flights that go across time zones.

In summary, our meta-analysis shows that pilots have a significantly increased risk of prostate cancer. The difference between the pilots and cabin crew is difficult to explain by circadian rhythm disorder or cosmic radiation and could be due to uncontrolled confounding. The evidence suggests that the association between the pilots and prostate cancer is possible.

\section{Occupational physical activity}

It has been shown that physical activity reduces the risk of several cancers, including prostate cancer [254]. Studies of physical activity at work, however, have produced conflicting results regarding the risk for prostate cancer [255]. In our meta-analysis we found that physical activity at work was associated with a non-significant reduced risk $(\mathrm{RR}=0.90 ; 95 \% \mathrm{CI}$ $=0.80-1.02$ ). Meta-analysis showed a great heterogeneity, which could be due to the difficulty in recalling the physical strain at work in the past. However, in 10 included cohort studies, the risk was significantly reduced ( $R R=0.87 ; 95 \% C I=0.81-0.94$ ), and studies were consistent. In the remaining eight case-control studies reduced risk was of the same magnitude, but not statistically significant $(\mathrm{RR}=0.91 ; 95 \% \mathrm{CI}=0.69-1.20)$ with a high heterogeneity.

In the meta-analysis published by Liu et al. [66] a significantly reduced risk of prostate cancer was found for those who had a higher level of physical activity at work (27 trials; RR $=0.81,95 \%$ $\mathrm{CI}=0.73-0.91)$. Similar results were reported for separate meta-analysis of cohort and case-control studies $(R R=0.91 ; 95 \%$ $\mathrm{CI}=0.80-0.95$ and $\mathrm{RR}=0.73 ; 95 \% \mathrm{CI}=0.68-0.87$, respectively). Several studies included in this meta-analysis were excluded from our meta-analysis due to the weak definition of physical activity and because patients with other cancers were used as controls.

A frequent problem with studies of occupational physical activity is a poor definition of exposure. Four studies in our meta-analysis had a good quality of assessed occupational physical activity that included information on the exposure frequency, intensity and duration, which allowed the estimation of total exposure over time $[137,138,145,150]$. Several studies estimated exposure based on one or two questions $[135,139,140,143,144,147,149]$. Lund Nilsen et al. [144] based the exposure assessment on the single question of whether "worker felt physically exhausted after a day's work". The study by Zeegers et al. [151] defined walking and cycling to and from work as a recreational physical activity. Four studies estimated exposure on only occupational title $[134,136,142,151]$ which is an uncertain variable having in mind a great difference in exposure intensity within the same occupations as well as over time in the same occupation.

In most of studies, physical activity is estimated based on self-report, not objective enough measure of exposure. Specifically, case-control studies may contain a recall bias. Cohort studies usually report the exposure before or at the time of inclusion in the study with no data on exposure during follow-up.

We can summarize that there is weak evidence that physical activity at work is associated with a reduced risk of prostate cancer.

\section{Farming}

Total mortality rates in farmers and other agricultural workers are often lower compared to the general population and many other occupations, which has been attributed to a healthy lifestyle, and lower smoking prevalence [20,256]. However, farmer's occupation involves a wide range of tasks, including care of animals, handling of feed, seed and animal wastes, salvage of hay and various grains, driving tractors and other vehicles, handling different machines and tools, maintenance and repair. Therefore, they have multiple exposures, such as organic and inorganic dust, pesticides, fungi, microbes, viruses, oils, gasoline, diesel exhaust, welding fumes, and ultraviolet light [15].

Since the 1970s, more studies reported significant excess risk of prostate cancer among farmers compared to other occupations $[20,257,258]$. In the 1980 s a series of studies were initiated to identify specific carcinogens associated with farm work.

Our meta-analysis provided no evidence that farm work was associated with increased risk of prostate cancer (metaRR $=0.99$; $95 \% \mathrm{CI}=0.95-1.02)$, based on 26 included studies from 15 countries with a total of 66,749 cases, and with a moderate degree of heterogeneity in the results. This is consistent with the meta-analysis by Van Maele-Fabry and Willems [30] based on 11 studies (metaRR $=0.97 ; 95 \% \mathrm{CI}=0.92-1.03$ ). However, some previous meta-analyses found excess risk for prostate cancer among farmers such as an early meta-analysis of 22 studies by Blair et al. [32] reporting risk of 1.08 (95\% CI $=1.06-1.11$ ), followed by meta-analysis of 24 studies by Keller-Byrne et al. [16] (metaRR $=1.12 ; 95 \% \mathrm{CI}=1.01-1.24$ ), and the meta-analysis by Acquavella et al. [259], which included 30 studies ( $R R=1.07 ; 95 \%$ $\mathrm{CI}=1.02-1.13)$. Meta-analyses by Keller-Byrne et al. [16] and 
Acquavella et al. [259] included proportional mortality studies (PMR) (three vs. one, respectively) and the later one included nine studies not published in international peer review journals. The recent meta-analysis of twelve case-control studies by Ragin et al. [11] showed significantly elevated risks for farmers and agricultural workers, irrespective of the way of control selection, i.e., when controls were people diagnosed with benign prostatic hyperplasia the risk estimate was 3.83 (1.96-7.48), while when controls were persons free of benign prostatic hyperplasia the risk was 1.38 (1.16-1.64). However, inclusion of unpublished studies in all three meta-analyses $[11,16,259]$ can be a source of a methodological weakness due to the possible lower quality of selected studies not being ready for publication.

The inconsistent results may occur for many reasons such as different study designs as studies performed prior to 1990 were often PMR, generally regarded as having a lower quality than longitudinal studies and giving higher risk estimates. This was documented in the meta-analysis of Acquavella et al. [259], who performed a separate analysis for PMR and cohort studies and reported higher risk in the former $($ metaRR $=1.12 ; 95 \% \mathrm{CI}=$ 1.08-1.18 vs. metaRR $=0.95 ; 95 \% \mathrm{CI}=0.93-0.98$, respectively). Second, studies from different geographical areas might reflect different work practice, use of different pesticides, etc., as was shown in the study of Van Maele-Fabry and Willems [30] who concluded that studies derived from the USA and Canada reported a non-significantly elevated risk among farmers $(\mathrm{RR}=$ 1.26; $95 \% \mathrm{CI}=0.83-1.90 ; 5$ studies), whereas farmers in Europe had non-significantly decreased risk $(0.96 ; 95 \% \mathrm{CI}=0.92-1.01 ; 6$ studies).

\section{Organophosphate pesticides}

Our analysis of organophosphate pesticides showed no increased risk of prostate cancer $($ metaRR $=0.98 ; 95 \% \mathrm{CI}=$ 0.87-1.11), heterogeneity in results was low. The pesticide associated with the highest risk of prostate cancer was dichlorvos [111], an insecticide classified as a possible carcinogen by the IARC [229] based on animal studies. No more epidemiological studies supporting association between dichlorvos and prostate cancer were found.

\section{Carbamates}

Meta-analysis of carbamates showed a non-significant increase in risk for prostate cancer (metaRR $=1.05 ; 95 \% \mathrm{CI}=0.89-1.24$ ) and the heterogeneity was low. The single study showed significantly increased risk of prostate cancer due to exposure to butylates ( $\mathrm{RR}=1.44 ; 95 \% \mathrm{CI}=1.04-1.99)$ [180]. This study, a part of the AHS cohort, reported also a dose-response relationship.

\section{Triazines}

Meta-analysis of triazines showed a slightly elevated risk, not statistically significant (metaRR $=1.02 ; 95 \% \mathrm{CI}=0.92-1.14$ ). The increase in risk of prostate cancer was reported among workers in production of atrazine [184], and farmers applying simazine [111], both belonging to the chlorotriazines. However, in both studies increased risk was insignificant. The later study reported a dose-response relationship. Data from the literature were insufficient to support carcinogenicity of chlorotriazine.

\section{Cadmium}

IARC [260] classified cadmium as a carcinogen. Some earlier studies reported causal relationship between cadmium exposure and prostate cancer, but this could not be confirmed in later epidemiologic studies [38]. Cadmium is used in a production of nickel-cadmium batteries, soldering alloys, pigments, stabilizer, coatings, etc.

We found an insignificant excess of risk for prostate cancer related to cadmium exposure (metaRR $=1.12 ; 95 \% \mathrm{CI}=$ 0.92-1.14). Our results are consistent with the conclusions of the meta-analysis by Sahmoun et al. [34] of 21 studies published in 2005 that reported statistically non-significant excess of risk (summary SMR score $=126 ; 95 \% \mathrm{CI}=83-184$ ). Several narrative reviews $[2,33,35]$ concluded that existing studies in humans, particularly recent ones, could not confirm that cadmium exposure can result in excess risk of prostate cancer.

\section{Cutting fluids}

When talking about cutting fluids we consider fluids that are used in metalworking to lubricate and cool. They are usually classified as cutting oils based on mineral oil or synthetic oil, water soluble cutting fluids, mostly in the form of water-oil emulsion, and synthetic fluids which do not contain mineral oils. Cutting fluids contain several suspected carcinogens, such as aliphatic hydrocarbons, polycyclic aromatic hydrocarbons, nitrosamines, and certain metals [42] and are commonly used in metal manufacturing and in mechanical workshops.

Our meta-analysis showed no evidence that exposure to cutting fluids could be associated with the increased risk of prostate cancer (metaRR $=1.03 ; 95 \% \mathrm{CI}=0.91-1.16$ ), heterogeneity did not exist. The review article of six studies by Tolbert [42] provided a limited evidence that metalworking fluids can be associated with prostate cancer. A major methodological problem in studies of cutting fluids is that the workers exposed to cutting 
fluids are also exposed to other chemicals such as metals and solvents which may increase the risk of prostate cancer.

In this review, data from selected studies were too limited to analyze the various cutting fluids separately. There is no sufficient evidence that exposure to cutting fluids increases the risk of prostate cancer.

\section{Acrylonitrile}

Acrylonitrile has been used since the 1920s, mostly to produce acrylic fiber, necessary material in the apparel industry. Following the experiments on animals showing that acrylonitrile could be carcinogenic, a first epidemiological study was conducted among the workers exposed to acrylonitrile in a German plant, but no excess risk of cancers was reported [261]. In 1980s the epidemiologic studies were performed in USA [262] and Germany [263], however only study in the USA at a plant producing fibers reported three prostate cancer cases vs. 0.9 expected. Later series of epidemiological studies did not support an association of exposure to acrylonitrile in different plants and prostate cancer [196,198,264], with exception of a follow-up study by O'Berg et al. [265] that reported 6 prostate cancers against 1.8 expected. In 1999 IARC [266] classified acrylonitrile as possible human carcinogen.

Our meta-analysis showed no increased risk of prostate cancer ( $\mathrm{RR}=0.93 ; 95 \% \mathrm{CI}=0.71-1.21)$ and study results were consistent. This is in line with the meta-analysis by Rothman [267] who included eight studies, and Collins and Acquavella [71] who included 25 studies, but no increased risk estimates for prostate cancer were reported. The overview article by Cole et al. [70] did not support a causal relationship between acrylonitrile exposure and prostate cancer. There is no enough evidence that acrylonitrile increases the risk of prostate cancer.

\section{Rubber manufacturing}

Carcinogenic risk in rubber industry such as in cable and tire production and rubber goods manufacturing was evaluated by IARC in 1982 and 1987 and was classified as definitely carcinogenic (Group 1), mostly due to exposure to aromatic amines and solvents $[268,269]$. However, excess risk of prostate cancer was not demonstrated.

Our meta-analysis, which included 15 studies, showed no increased risk of prostate cancer in workers in the rubber and tire industry (metaRR $=0.98 ; 95 \% \mathrm{CI}=0.87-1.09$ ). Heterogeneity was moderate. Previously published meta-analyzes showed similar results. Meta-analysis by Stewart et al. [45] included 12 studies and reported the risk estimate of 1.03 ( $95 \% \mathrm{CI}=0.96-1.11$ ).
Similarly, the review article by Kogevinas et al. [46] found no evidence of increased risk of prostate cancer in the rubber industry. Mullins and Loeb [12] summarized the findings from six studies and reported that no specific occupational exposure in rubber industry had shown conclusive evidence of an association with prostate cancer.

According to our assessment, there is no evidence that exposures in the rubber and tire industry increase the risk of prostate cancer.

\section{Whole body vibration}

Occupational exposure to WBV is common in drivers of heavy vehicles, such as forest machines, tractors and other construction vehicles. However, the exposure can vary in a great extend depending on the conditions of surface they are driving on and the dampers provided in the vehicle during the working hours. Moreover, professional drivers can also have other carcinogenic exposures.

Our results found a slightly lower risk estimates $(R R=1.03$; $95 \% \mathrm{CI}=0.98-1.09$ ) than the meta-analysis by Young et al. [44], who reported a risk of 1.14 (95\% CI $=0.99-1.30)$. In Young's analysis [44], however, two included studies used other cancers as controls. Heterogeneity in our meta-analysis was high, probably because the weak exposure assessment in all original studies based on job titles that included all types of vehicle drivers. Three included studies used questionnaires and interviews supplemented by expert judgment to assess exposure to WBV [147,215,218]. Even in these cases, there are shortcomings. The study by Nadalin et al. [218] assessed the exposure intensity referring to information from a German website, which however could not be obtained in a search. Moreover, authors created an index of the WBV by multiplying these data with their own measurements. Similar method of exposure assessment was done in the study by Jones et al. [215] while in the article by Sass-Kortsak et al. [147] WBV variable was not defined clear enough and was based on positive answer (yes) on the question: "Longest job in occupation with whole-body vibration".

Based on our assessment there is no evidence that WBV is a risk factor for prostate cancer.

\section{6. lonizing radiation}

Ionizing radiation is one of the most extensively studied carcinogens. Case reports have been published starting the late 1800s. Since 1902 when the association between exposure to ionizing radiation among radiologists and skin cancer was 
published, knowledge about the ionizing radiation has accumulated [270]. IARC evaluated ionizing radiation in 2000 and 2012 and concluded that X- and $\gamma$-radiation were carcinogens [271,272]. However, not a clear relationship is established for prostate cancer [273].

Our meta-analysis did not provide evidence that exposure to ionizing radiation increased the risk of prostate cancer $(\mathrm{RR}=$ 1.07; 95\% CI = 0.97-1.17); heterogeneity was moderate. Studies examined workers occupationally exposed to ionizing radiation from nuclear plants, nuclear research centers, nuclear tests and radiologic technicians. Strength of the included studies is that personal dosimeters were used for exposure assessment; exception is the study of radiological technicians. A meta-analysis by Park et al. [274], which included 11 studies, showed a significantly reduced risk of prostate cancer $(\mathrm{RR}=0.84 ; 95 \% \mathrm{CI}=$ 0.75-0.96). Follow-up studies of populations that survived the atomic bombs dropped on Japan in 1945 did not show that the risk of prostate cancer was increased $(\mathrm{RR}=0.29 ; 95 \% \mathrm{CI}=$ 0.21-1.2) [275].

Epidemiologic studies demonstrated no association between ionizing radiation and prostate cancer.

\section{SUMMARY}

Prostate cancer is the most common cancer in men in the western developed world. Heredity and age play a major role in the development of prostate cancer. The significance of occupational exposures is uncertain. Our literature review supports a causal association for a few of the previously suggested factors, such as pesticides, chromium, and shift work are significantly associated with prostate cancer, as well as occupational physical activity. The highest risk estimates for prostate cancer of $25 \%$ was revealed for shift work, which included night shifts. The pilots, occupation sometimes used as a surrogate for the night shift exposure, had an increased risk of $41 \%$, however, the exposure assessment was not uniform, and pilots do not always have shift work. We found increased risk for pesticide exposure in general, and separately for organochlorine pesticides. It was not possible to identify individual pesticides as carcinogenic. Exposure assessment in studies with occupational exposure to pesticide is also a concern as workers often use multiple pesticides simultaneously or over time, and possible uncontrolled confounding may also be present. Chromium exposure increased the risk for prostate cancer of 19\%. All included studies on chromium were cohort studies and results were consistent. Weak association with occupational physical activated was observed.

\section{ACKNOWLEDGMENTS}

This work was a part of the series of systematic reviews of occupational health problems issued by the University of Gothenburg. It was funded by AFA Insurance.

We would like to thank Kjell Toren, Maria Albin and Bengt Jarvholm for their support and valuable comments reviewing the article.

\section{CONFLICTS OF INTEREST}

No potential conflicts of interest were disclosed.

\section{SUPPLEMENTARY MATERIALS}

Supplementary materials can be found via https://doi.org/ 10.15430/JCP.2019.24.2.100

\section{REFERENCES}

1. Ferlay J, Soerjomataram I, Dikshit R, Eser S, Mathers C, Rebelo $\mathrm{M}$, et al. Cancer incidence and mortality worldwide: sources, methods and major patterns in GLOBOCAN 2012. Int J Cancer 2015;136:E359-86.

2. Platz EA, Giovannucci E. Prostate cancer. In: Schottenfeld D, Fraumeni JF, eds. Cancer Epidemiology and Prevention. 3rd ed. New York, Oxford University Press, pp 1128-50, 2006.

3. Ferlay J, Steliarova-Foucher E, Lortet-Tieulent J, Rosso S, Coebergh JW, Comber H, et al. Cancer incidence and mortality patterns in Europe: estimates for 40 countries in 2012. Eur J Cancer 2013;49:1374-403.

4. Steinberg GD, Carter BS, Beaty TH, Childs B, Walsh PC. Family history and the risk of prostate cancer. Prostate 1990;17:337-47.

5. Lichtenstein P, Holm NV, Verkasalo PK, Iliadou A, Kaprio J, Koskenvuo M, et al. Environmental and heritable factors in the causation of cancer-analyses of cohorts of twins from Sweden, Denmark, and Finland. N Engl J Med 2000;343:78-85.

6. Bratt O, Drevin L, Akre O, Garmo H, Stattin P. Family history and probability of prostate cancer, differentiated by risk category: a nationwide population-based study. J Natl Cancer Inst 2016;108:djw110.

7. Martin DN, Starks AM, Ambs S. Biological determinants of health disparities in prostate cancer. Curr Opin Oncol 2013;25:235-41.

8. Zuo L, Ren KW, Bai Y, Zhang LF, Zou JG, Qin XH, et al. Association of a common genetic variant in RNASEL and prostate cancer susceptibility. Oncotarget 2017;8:75141-50.

9. Su LJ, Fontham ET. Prostate cancer: an occupational hazard? Future Oncol 2014;10:903-6.

10. Doolan G, Benke G, Giles G. An update on occupation and pros- 
tate cancer. Asian Pac J Cancer Prev 2014;15:501-16.

11. Ragin C, Davis-Reyes B, Tadesse H, Daniels D, Bunker CH, Jackson $\mathrm{M}$, et al. Farming, reported pesticide use, and prostate cancer. Am J Mens Health 2013;7:102-9.

12. Mullins JK, Loeb S. Environmental exposures and prostate cancer. Urol Oncol 2012;30:216-9.

13. Bostwick DG, Burke HB, Djakiew D, Euling S, Ho SM, Landolph J, et al. Human prostate cancer risk factors. Cancer 2004;101: 2371-490.

14. Golka K, Wiese A, Assennato G, Bolt HM. Occupational exposure and urological cancer. World J Urol 2004:21:382-91.

15. Parent ME, Siemiatycki J. Occupation and prostate cancer. Epidemiol Rev 2001;23:138-43.

16. Keller-Byrne JE, Khuder SA, Schaub EA. Meta-analyses of prostate cancer and farming. Am J Ind Med 1997;31:580-6.

17. Van Der Gulden JW, Vogelzang PF. Farmers at risk for prostate cancer. Br J Urol 1996;77:6-14.

18. Blair A, Zahm SH. Agricultural exposures and cancer. Environ Health Perspect 1995;103 Suppl 8:205-8.

19. Davis DL, Blair A, Hoel DG. Agricultural exposures and cancer trends in developed countries. Environ Health Perspect 1993; 100:39-44.

20. Blair A, Malker H, Cantor KP, Burmeister L, Wiklund K. Cancer among farmers. A review. Scand J Work Environ Health 1985:11:397-407.

21. Alavanja MC, Ross MK, Bonner MR. Increased cancer burden among pesticide applicators and others due to pesticide exposure. CA Cancer J Clin 2013;63:120-42.

22. Sathiakumar N, MacLennan PA, Mandel J, Delzell E. A review of epidemiologic studies of triazine herbicides and cancer. Crit Rev Toxicol 2011:41 Suppl 1:1-34.

23. Clapp RW, Jacobs MM, Loechler EL. Environmental and occupational causes of cancer: new evidence 2005-2007. Rev Environ Health 2008;23:1-37.

24. Mink PJ, Adami HO, Trichopoulos D, Britton NL, Mandel JS. Pesticides and prostate cancer: a review of epidemiologic studies with specific agricultural exposure information. Eur J Cancer Prev 2008;17:97-110.

25. Van Maele-Fabry G, Libotte V, Willems J, Lison D. Review and meta-analysis of risk estimates for prostate cancer in pesticide manufacturing workers. Cancer Causes Control 2006;17:353-73.

26. Jaga $\mathrm{K}$, Dharmani $\mathrm{C}$. The epidemiology of pesticide exposure and cancer: a review. Rev Environ Health 2005;20:15-38.

27. Van Maele-Fabry G, Willems JL. Prostate cancer among pesticide applicators: a meta-analysis. Int Arch Occup Environ Health 2004;77:559-70.

28. Ejaz S, Akram W, Lim CW, Lee JJ, Hussain I. Endocrine disrupting pesticides: a leading cause of cancer among rural people in Pakistan. Exp Oncol 2004:26:98-105.

29. Alavanja MC, Hoppin JA, Kamel F. Health effects of chronic pesticide exposure: cancer and neurotoxicity. Annu Rev Public Health 2004:25:155-97.

30. Van Maele-Fabry G, Willems JL. Occupation related pesticide exposure and cancer of the prostate: a meta-analysis. Occup Environ Med 2003;60:634-42.

31. Morrison HI, Wilkins K, Semenciw R, Mao Y, Wigle D. Herbicides and cancer. J Natl Cancer Inst 1992;84:1866-74.

32. Blair A, Zahm SH, Pearce NE, Heineman EF, Fraumeni JF Jr. Clues to cancer etiology from studies of farmers. Scand J Work
Environ Health 1992;18:209-15.

33. Huff J, Lunn RM, Waalkes MP, Tomatis L, Infante PF. Cadmium-induced cancers in animals and in humans. Int J Occup Environ Health 2007;13:202-12.

34. Sahmoun AE, Case LD, Jackson SA, Schwartz GG. Cadmium and prostate cancer: a critical epidemiologic analysis. Cancer Invest 2005;23:256-63.

35. Verougstraete V, Lison D, Hotz P. Cadmium, lung and prostate cancer: a systematic review of recent epidemiological data. J Toxicol Environ Health B Crit Rev 2003;6:227-55.

36. Waalkes MP, Rehm S. Cadmium and prostate cancer. J Toxicol Environ Health 1994:43:251-69.

37. Kazantzis G, Blanks RG, Sullivan KR. Is cadmium a human carcinogen? IARC Sci Publ 1992;(118):435-46.

38. Boffetta P. Methodological aspects of the epidemiological association between cadmium and cancer in humans. In: Nordberg GF, Herber RF, Alessio L, eds. Cadmium in the Human Environment: Toxicity and Carcinogenicity. Lyon, International Agency for Research on Cancer (IARC), pp 425-34, 1992.

39. Hallenbeck WH. Human health effects of exposure to cadmium. Experientia 1984:40:136-42.

40. Flanders WD. Review: prostate cancer epidemiology. Prostate 1984:5:621-9.

41. Piscator M. Role of cadmium in carcinogenesis with special reference to cancer of the prostate. Environ Health Perspect 1981;40:107-20

42. Tolbert PE. Oils and cancer. Cancer Causes Control 1997;8: 386-405.

43. van der Gulden JW. Metal workers and repairmen at risk for prostate cancer: a review. Prostate 1997:30:107-16.

44. Young E, Kreiger N, Purdham J, Sass-Kortsak A. Prostate cancer and driving occupations: could whole body vibration play a role? Int Arch Occup Environ Health 2009;82:551-6.

45. Stewart RE, Dennis LK, Dawson DV, Resnick MI. A meta-analysis of risk estimates for prostate cancer related to tire and rubber manufacturing operations. J Occup Environ Med 1999;41: 1079-84.

46. Kogevinas M, Sala M, Boffetta P, Kazerouni N, Kromhout H, Hoar-Zahm S. Cancer risk in the rubber industry: a review of the recent epidemiological evidence. Occup Environ Med 1998:55:1-12.

47. Raslau D, Summerfield DT, Abu Dabrh AM, Steinkraus LW, Murad MH. The risk of prostate cancer in pilots: a meta-analysis. Aerosp Med Hum Perform 2015;86:112-7.

48. Yong M, Nasterlack M. Shift work and cancer: state of science and practical consequences. Arh Hig Rada Toksikol 2012;63: $153-60$.

49. Wang XS, Armstrong ME, Cairns BJ, Key TJ, Travis RC. Shift work and chronic disease: the epidemiological evidence. Occup Med (Lond) 2011;61:78-89.

50. Kolstad HA. Nightshift work and risk of breast cancer and other cancers--a critical review of the epidemiologic evidence. Scand J Work Environ Health 2008;34:5-22.

51. Kim JN, Lee BM. Risk factors, health risks, and risk management for aircraft personnel and frequent flyers. J Toxicol Environ Health B Crit Rev 2007;10:223-34.

52. Davis S, Mirick DK. Circadian disruption, shift work and the risk of cancer: a summary of the evidence and studies in Seattle. Cancer Causes Control 2006;17:539-45. 
53. Buja A, Lange JH, Perissinotto E, Rausa G, Grigoletto F, Canova C, et al. Cancer incidence among male military and civil pilots and flight attendants: an analysis on published data. Toxicol Ind Health 2005:21:273-82.

54. Aw JJ. Cosmic radiation and commercial air travel. J Travel Med 2003;10:19-28.

55. Ballard T, Lagorio S, De Angelis G, Verdecchia A. Cancer incidence and mortality among flight personnel: a meta-analysis. Aviat Space Environ Med 2000;71:216-24.

56. Chang ET, Boffetta P, Adami HO, Cole P, Mandel JS. A critical review of the epidemiology of Agent Orange/TCDD and prostate cancer. Eur J Epidemiol 2014:29:667-723.

57. Girschik J, Glass D, Ambrosini GL, Fritschi L. Could mining be protective against prostate cancer? A study and literature review. Occup Environ Med 2010;67:365-74.

58. Cole P, Rodu B. Epidemiologic studies of chrome and cancer mortality: a series of meta-analyses. Regul Toxicol Pharmacol 2005:43:225-31.

59. Golden R, Kimbrough R. Weight of evidence evaluation of potential human cancer risks from exposure to polychlorinated biphenyls: an update based on studies published since 2003. Crit Rev Toxicol 2009;39:299-331.

60. Di Trolio R, Di Lorenzo G, Fumo B, Ascierto PA. Cosmic radiation and cancer: is there a link? Future Oncol 2015;11:1123-35.

61. Axelson O, Forastiere F. Radon as a risk factor for extra-pulmonary tumours. Med Oncol Tumor Pharmacother 1993;10:167-72.

62. Grant WB. Update on evidence that support a role of solar ultraviolet-B irradiance in reducing cancer risk. Anticancer Agents Med Chem 2013;13:140-6.

63. Krause R, Matulla-Nolte B, Essers M, Brown A, Hopfenmüller W. UV radiation and cancer prevention: what is the evidence? Anticancer Res 2006;26:2723-7.

64. Heikkilä K, Nyberg ST, Theorell T, Fransson EI, Alfredsson L, Bjorner JB, et al. Work stress and risk of cancer: meta-analysis of 5700 incident cancer events in 116,000 European men and women. BMJ 2013;346:f165.

65. Anzuini F, Battistella A, Izzotti A. Physical activity and cancer prevention: a review of current evidence and biological mechanisms. J Prev Med Hyg 2011;52:174-80.

66. Liu Y, Hu F, Li D, Wang F, Zhu L, Chen W, et al. Does physical activity reduce the risk of prostate cancer? A systematic review and meta-analysis. Eur Urol 2011;60:1029-44.

67. Thune I, Furberg AS. Physical activity and cancer risk: dose-response and cancer, all sites and site-specific. Med Sci Sports Exerc 2001;33:S530-50; discussion S609-10.

68. Oliveria SA, Lee IM. Is exercise beneficial in the prevention of prostate cancer? Sports Med 1997;23:271-8.

69. Sternfeld B. Cancer and the protective effect of physical activity: the epidemiological evidence. Med Sci Sports Exerc 1992;24: 1195-209.

70. Cole P, Mandel JS, Collins JJ. Acrylonitrile and cancer: a review of the epidemiology. Regul Toxicol Pharmacol 2008;52:342-51.

71. Collins JJ, Acquavella JF. Review and meta-analysis of studies of acrylonitrile workers. Scand J Work Environ Health 1998;24 Suppl 2:71-80.

72. Budnik LT, Kloth S, Velasco-Garrido M, Baur X. Prostate cancer and toxicity from critical use exemptions of methyl bromide: environmental protection helps protect against human health risks. Environ Health 2012;11:5.

73. Mundt KA, Birk T, Burch MT. Critical review of the epidemiological literature on occupational exposure to perchloroethylene and cancer. Int Arch Occup Environ Health 2003;76:473-91.

74. Gibbs GW, Labrèche F. Cancer risks in aluminum reduction plant workers: a review. J Occup Environ Med 2014:56:S40-59.

75. Liu $\mathrm{T}, \mathrm{Xu} \mathrm{QE}$, Zhang $\mathrm{CH}$, Zhang P. Occupational exposure to methylene chloride and risk of cancer: a meta-analysis. Cancer Causes Control 2013;24:2037-49.

76. LeMasters GK, Genaidy AM, Succop P, Deddens J, Sobeih T, Barriera-Viruet $\mathrm{H}$, et al. Cancer risk among firefighters: a review and meta-analysis of 32 studies. J Occup Environ Med 2006; 48:1189-202.

77. Thorn J, Kerekes E. Health effects among employees in sewage treatment plants: a literature survey. Am J Ind Med 2001;40: 170-9.

78. Wong O, Raabe GK. A critical review of cancer epidemiology in the petroleum industry, with a meta-analysis of a combined database of more than 350,000 workers. Regul Toxicol Pharmacol 2000;32:78-98.

79. Mehlman MA. Dangerous and cancer-causing properties of products and chemicals in the oil refining and petrochemical industry. VIII. Health effects of motor fuels: carcinogenicity of gasoline--scientific update. Environ Res 1992;59:238-49.

80. Chang ET, Adami HO, Boffetta P, Cole P, Starr TB, Mandel JS. A critical review of perfluorooctanoate and perfluorooctanesulfonate exposure and cancer risk in humans. Crit Rev Toxicol 2014:44 Suppl 1:1-81.

81. Rothman KJ, Boice JD Jr. Epidemiologic analysis with a programmable calculator. Bethesda, National Institute of Health, pp 31-32, 1979.

82. Higgins JP, Thompson SG, Deeks JJ, Altman DG. Measuring inconsistency in meta-analyses. BMJ 2003;327:557-60.

83. Alberghini V, Luberto F, Gobba F, Morelli C, Gori E, Tomesani N. Mortality among male farmers licensed to use pesticides. Med Lav 1991;82:18-24.

84. Beard J, Sladden T, Morgan G, Berry G, Brooks L, McMichael A. Health impacts of pesticide exposure in a cohort of outdoor workers. Environ Health Perspect 2003;111:724-30.

85. Boers D, Zeegers MP, Swaen GM, Kant I, van den Brandt PA. The influence of occupational exposure to pesticides, polycyclic aromatic hydrocarbons, diesel exhaust, metal dust, metal fumes, and mineral oil on prostate cancer: a prospective cohort study. Occup Environ Med 2005;62:531-7.

86. Cantor KP, Silberman W. Mortality among aerial pesticide applicators and flight instructors: follow-up from 1965-1988. Am J Ind Med 1999:36:239-47.

87. Dich J, Wiklund K. Prostate cancer in pesticide applicators in Swedish agriculture. Prostate 1998;34:100-12.

88. Ewings P, Bowie C. A case-control study of cancer of the prostate in Somerset and east Devon. Br J Cancer 1996;74:661-6.

89. Figà-Talamanca I, Mearelli I, Valente P, Bascherini S. Cancer mortality in a cohort of rural licensed pesticide users in the province of Rome. Int J Epidemiol 1993;22:579-83.

90. Fleming LE, Bean JA, Rudolph M, Hamilton K. Cancer incidence in a cohort of licensed pesticide applicators in Florida. J Occup Environ Med 1999:41:279-88.

91. Fleming LE, Gómez-Marín O, Zheng D, Ma F, Lee D. National Health Interview Survey mortality among US farmers and pesti- 
cide applicators. Am J Ind Med 2003:43:227-33.

92. Fritschi L, Glass DC, Tabrizi JS, Leavy JE, Ambrosini GL. Occupational risk factors for prostate cancer and benign prostatic hyperplasia: a case-control study in Western Australia. Occup Environ Med 2007;64:60-5.

93. Frost G, Brown T, Harding AH. Mortality and cancer incidence among British agricultural pesticide users. Occup Med (Lond) 2011;61:303-10.

94. Koutros S, Alavanja MC, Lubin JH, Sandler DP, Hoppin JA, Lynch $\mathrm{CF}$, et al. An update of cancer incidence in the Agricultural Health Study. J Occup Environ Med 2010;52:1098-105.

95. Meyer TE, Coker AL, Sanderson M, Symanski E. A case-control study of farming and prostate cancer in African-American and Caucasian men. Occup Environ Med 2007;64:155-60.

96. Sperati A, Rapiti E, Settimi L, Quercia A, Terenzoni B, Forastiere F. Mortality among male licensed pesticide users and their wives. Am J Ind Med 1999;36:142-6.

97. Subahir MN, Shah SA, Zainuddin ZM. Risk factors for prostate cancer in Universiti Kebangsaan Malaysia Medical Centre: a case-control study. Asian Pac J Cancer Prev 2009;10:1015-20.

98. Torchio P, Lepore AR, Corrao G, Comba P, Settimi L, Belli S, et al. Mortality study on a cohort of Italian licensed pesticide users. Sci Total Environ 1994:149:183-91.

99. van der Gulden JW, Kolk JJ, Verbeek AL. Work environment and prostate cancer risk. Prostate 1995:27:250-7.

100. Zhong Y, Rafnsson V. Cancer incidence among Icelandic pesticide users. Int J Epidemiol 1996;25:1117-24.

101. Alavanja MC, Samanic C, Dosemeci M, Lubin J, Tarone R, Lynch $\mathrm{CF}$, et al. Use of agricultural pesticides and prostate cancer risk in the Agricultural Health Study cohort. Am J Epidemiol 2003; 157:800-14.

102. Aronson KJ, Wilson JW, Hamel M, Diarsvitri W, Fan W, Woolcott C, et al. Plasma organochlorine levels and prostate cancer risk. J Expo Sci Environ Epidemiol 2010;20:434-45.

103. Asp S, Riihimäki V, Hernberg S, Pukkala E. Mortality and cancer morbidity of Finnish chlorophenoxy herbicide applicators: an 18-year prospective follow-up. Am J Ind Med 1994:26:243-53.

104. Burns CJ, Beard KK, Cartmill JB. Mortality in chemical workers potentially exposed to 2,4-dichlorophenoxyacetic acid (2,4-D) 1945-94: an update. Occup Environ Med 2001;58:24-30.

105. Coggon D, Ntani G, Harris EC, Jayakody N, Palmer KT. Soft tissue sarcoma, non-Hodgkin's lymphoma and chronic lymphocytic leukaemia in workers exposed to phenoxy herbicides: extended follow-up of a UK cohort. Occup Environ Med 2015;72:435-41.

106. Hardell L, Andersson SO, Carlberg M, Bohr L, van Bavel B, Lindström $\mathrm{G}$, et al. Adipose tissue concentrations of persistent organic pollutants and the risk of prostate cancer. J Occup Environ Med 2006;48:700-7.

107. Kogevinas M, Becher H, Benn T, Bertazzi PA, Boffetta P, Bueno-de-Mesquita HB, et al. Cancer mortality in workers exposed to phenoxy herbicides, chlorophenols, and dioxins. An expanded and updated international cohort study. Am J Epidemiol 1997; 145:1061-75.

108. Koutros S, Beane Freeman LE, Lubin JH, Heltshe SL, Andreotti $\mathrm{G}$, Barry KH, et al. Risk of total and aggressive prostate cancer and pesticide use in the Agricultural Health Study. Am J Epidemiol 2013;177:59-74.

109. Lee WJ, Hoppin JA, Blair A, Lubin JH, Dosemeci M, Sandler DP, et al. Cancer incidence among pesticide applicators exposed to alachlor in the Agricultural Health Study. Am J Epidemiol 2004:159:373-80.

110. Lynge E. Cancer incidence in Danish phenoxy herbicide workers, 1947-1993. Environ Health Perspect 1998;106 Suppl 2:683-8.

111. Mills PK, Yang R. Prostate cancer risk in California farm workers. J Occup Environ Med 2003;45:249-58.

112. Mozzachio AM, Rusiecki JA, Hoppin JA, Mahajan R, Patel R, Beane-Freeman L, et al. Chlorothalonil exposure and cancer incidence among pesticide applicator participants in the agricultural health study. Environ Res 2008;108:400-3.

113. Multigner L, Ndong JR, Giusti A, Romana M, Delacroix-Maillard $\mathrm{H}$, Cordier S, et al. Chlordecone exposure and risk of prostate cancer. J Clin Oncol 2010;28:3457-62.

114. Ritchie JM, Vial SL, Fuortes LJ, Guo H, Reedy VE, Smith EM. Organochlorines and risk of prostate cancer. J Occup Environ Med 2003:45:692-702.

115. Samanic C, Rusiecki J, Dosemeci M, Hou L, Hoppin JA, Sandler DP, et al. Cancer incidence among pesticide applicators exposed to dicamba in the agricultural health study. Environ Health Perspect 2006;114:1521-6.

116. Sawada N, Iwasaki M, Inoue M, Itoh H, Sasazuki S, Yamaji T, et al. Plasma organochlorines and subsequent risk of prostate cancer in Japanese men: a nested case-control study. Environ Health Perspect 2010;118:659-65.

117. Axelsson G, Rylander R, Schmidt A. Mortality and incidence of tumours among ferrochromium workers. Br J Ind Med 1980; 37:121-7.

118. Gibb HJ, Lees PS, Pinsky PF, Rooney BC. Lung cancer among workers in chromium chemical production. Am J Ind Med 2000;38:115-26.

119. Huvinen M, Pukkala E. Cancer incidence among Finnish ferrochromium and stainless steel production workers in 1967-2011: a cohort study. BMJ Open 2013;3:e003819.

120. Jakobsson K, Mikoczy Z, Skerfving S. Deaths and tumours among workers grinding stainless steel: a follow up. Occup Environ Med 1997;54:825-9.

121. Knutsson A, Damber L, Järvholm B. Cancers in concrete workers: results of a cohort study of 33,668 workers. Occup Environ Med 2000;57:264-7.

122. Langård S, Andersen A, Ravnestad J. Incidence of cancer among ferrochromium and ferrosilicon workers: an extended observation period. Br J Ind Med 1990;47:14-9.

123. Rafnsson V, Gunnarsdottir H, Kiilunen M. Risk of lung cancer among masons in Iceland. Occup Environ Med 1997;54:184-8.

124. Sorahan T, Harrington JM. Lung cancer in Yorkshire chrome platers, 1972-97. Occup Environ Med 2000;57:385-9.

125. Conlon M, Lightfoot N, Kreiger N. Rotating shift work and risk of prostate cancer. Epidemiology 2007;18:182-3.

126. Gapstur SM, Diver WR, Stevens VL, Carter BD, Teras LR, Jacobs EJ. Work schedule, sleep duration, insomnia, and risk of fatal prostate cancer. Am J Prev Med 2014;46:S26-33.

127. Kubo T, Ozasa K, Mikami K, Wakai K, Fujino Y, Watanabe Y, et al. Prospective cohort study of the risk of prostate cancer among rotating-shift workers: findings from the Japan collaborative cohort study. Am J Epidemiol 2006;164:549-55.

128. Papantoniou K, Castaño-Vinyals G, Espinosa A, Aragonés N, Pérez-Gómez B, Burgos J, et al. Night shift work, chronotype and prostate cancer risk in the MCC-Spain case-control study. Int J 
Cancer 2015; 137:1147-57.

129. Parent MÉ, El-Zein M, Rousseau MC, Pintos J, Siemiatycki J. Night work and the risk of cancer among men. Am J Epidemiol 2012;176:751-9.

130. Yong M, Blettner M, Emrich K, Nasterlack M, Oberlinner C, Hammer GP. A retrospective cohort study of shift work and risk of incident cancer among German male chemical workers. Scand J Work Environ Health 2014:40:502-10.

131. Band PR, Le ND, Fang R, Deschamps M, Coldman AJ, Gallagher $\mathrm{RP}$, et al. Cohort study of air Canada pilots: mortality, cancer incidence, and leukemia risk. Am J Epidemiol 1996;143:137-43.

132. Irvine D, Davies DM. British Airways flight deck mortality study, 1950-1992. Aviat Space Environ Med 1999;70:548-55.

133. Hammer GP, Auvinen A, De Stavola BL, Grajewski B, Gundestrup M, Haldorsen T, et al. Mortality from cancer and other causes in commercial airline crews: a joint analysis of cohorts from 10 countries. Occup Environ Med 2014:71:313-22.

134. Bairati I, Larouche R, Meyer F, Moore L, Fradet Y. Lifetime occupational physical activity and incidental prostate cancer (Canada). Cancer Causes Control 2000;11:759-64.

135. Clarke G, Whittemore AS. Prostate cancer risk in relation to anthropometry and physical activity: the National Health and Nutrition Examination Survey I Epidemiological Follow-Up Study. Cancer Epidemiol Biomarkers Prev 2000;9:875-81.

136. Doolan GW, Benke G, Giles GG, Severi G, Kauppinen T. A case control study investigating the effects of levels of physical activity at work as a risk factor for prostate cancer. Environ Health 2014;13:64.

137. Friedenreich CM, McGregor SE, Courneya KS, Angyalfi SJ, Elliott FG. Case-control study of lifetime total physical activity and prostate cancer risk. Am J Epidemiol 2004;159:740-9.

138. Grotta A, Bottai M, Adami HO, Adams SA, Akre O, Blair SN, et al. Physical activity and body mass index as predictors of prostate cancer risk. World J Urol 2015;33:1495-502.

139. Hartman TJ, Albanes D, Rautalahti M, Tangrea JA, Virtamo J, Stolzenberg R, et al. Physical activity and prostate cancer in the Alpha-Tocopherol, Beta-Carotene (ATBC) Cancer Prevention Study (Finland). Cancer Causes Control 1998:9:11-8.

140. Hrafnkelsdóttir SM, Torfadóttir JE, Aspelund T, Magnusson KT, Tryggvadóttir L, Gudnason V, et al. Physical activity from early adulthood and risk of prostate cancer: a 24-year follow-up study among Icelandic men. Cancer Prev Res (Phila) 2015;8:905-11.

141. Lacey JV Jr, Deng J, Dosemeci M, Gao YT, Mostofi FK, Sesterhenn IA, et al. Prostate cancer, benign prostatic hyperplasia and physical activity in Shanghai, China. Int J Epidemiol 2001;30:341-9.

142. Le Marchand L, Kolonel LN, Yoshizawa CN. Lifetime occupational physical activity and prostate cancer risk. Am J Epidemiol 1991;133:103-11.

143. Lund Håheim L, Wisløff TF, Holme I, Nafstad P. Metabolic syndrome predicts prostate cancer in a cohort of middle-aged Norwegian men followed for 27 years. Am J Epidemiol 2006; 164:769-74.

144. Lund Nilsen TI, Johnsen R, Vatten LJ. Socio-economic and lifestyle factors associated with the risk of prostate cancer. $\mathrm{Br} \mathrm{J}$ Cancer 2000;82:1358-63.

145. Orsini N, Bellocco R, Bottai M, Pagano M, Andersson SO, Johansson JE, et al. A prospective study of lifetime physical activity and prostate cancer incidence and mortality. $\mathrm{Br} \mathrm{J}$ Cancer
2009:101:1932-8.

146. Pierotti B, Altieri A, Talamini R, Montella M, Tavani A, Negri E, et al. Lifetime physical activity and prostate cancer risk. Int J Cancer 2005:114:639-42.

147. Sass-Kortsak AM, Purdham JT, Kreiger N, Darlington G, Lightfoot NE. Occupational risk factors for prostate cancer. Am J Ind Med 2007:50:568-76.

148. Severson RK, Nomura AM, Grove JS, Stemmermann GN. A prospective analysis of physical activity and cancer. Am J Epidemiol 1989;130:522-9.

149. Thune I, Lund E. Physical activity and the risk of prostate and testicular cancer: a cohort study of 53,000 Norwegian men. Cancer Causes Control 1994:5:549-56.

150. Wiklund F, Lageros YT, Chang E, Bälter K, Johansson JE, Adami $\mathrm{HO}$, et al. Lifetime total physical activity and prostate cancer risk: a population-based case-control study in Sweden. Eur J Epidemiol 2008:23:739-46.

151. Zeegers MP, Dirx MJ, van den Brandt PA. Physical activity and the risk of prostate cancer in the Netherlands cohort study, results after 9.3 years of follow-up. Cancer Epidemiol Biomarkers Prev 2005;14:1490-5.

152. Andersen A, Barlow L, Engeland A, Kjaerheim K, Lynge E, Pukkala E. Work-related cancer in the Nordic countries. Scand J Work Environ Health 1999;25 Suppl 2:1-116.

153. Andersson SO, Baron J, Bergström R, Lindgren C, Wolk A, Adami HO. Lifestyle factors and prostate cancer risk: a case-control study in Sweden. Cancer Epidemiol Biomarkers Prev 1996;5: 509-13.

154. Bouchardy C, Schüler G, Minder C, Hotz P, Bousquet A, Levi F, et al. Cancer risk by occupation and socioeconomic group among men: a study by the Association of Swiss Cancer Registries. Scand J Work Environ Health 2002;28 Suppl 1:1-88.

155. Bucchi L, Nanni O, Ravaioli A, Falcini F, Ricci R, Buiatti E, et al. Cancer mortality in a cohort of male agricultural workers from Northern Italy. J Occup Environ Med 2004:46:249-56.

156. Faustini A, Forastiere F, Di Betta L, Magliola EM, Perucci CA. Cohort study of mortality among farmers and agricultural workers. Med Lav 1993;84:31-41.

157. Fragar L, Depczynski J, Lower T. Mortality patterns of Australian male farmers and farm managers. Aust J Rural Health 2011; 19:179-84.

158. Franceschi S, Barbone F, Bidoli E, Guarneri S, Serraino D, Talamini R, et al. Cancer risk in farmers: results from a multi-site case-control study in north-eastern Italy. Int J Cancer 1993;53:740-5.

159. Gambini GF, Mantovani C, Pira E, Piolatto PG, Negri E. Cancer mortality among rice growers in Novara province, Northern Italy. Am J Ind Med 1997;31:435-41.

160. Ilić M, Vlajinac H, Marinković J. Case-control study of risk factors for prostate cancer. Br J Cancer 1996;74:1682-6.

161. Keller JE, Howe HL. Case-control studies of cancer in Illinois farmers using data from the Illinois State Cancer Registry and the U.S. Census of Agriculture. Eur J Cancer 1994:30:469-73.

162. Kristensen P, Andersen A, Irgens LM, Laake P, Bye AS. Incidence and risk factors of cancer among men and women in Norwegian agriculture. Scand J Work Environ Health 1996:22:14-26.

163. Krstev S, Baris D, Stewart PA, Hayes RB, Blair A, Dosemeci M. Risk for prostate cancer by occupation and industry: a 24-state death certificate study. Am J Ind Med 1998;34:413-20. 
164. Mastrangelo G, Grange JM, Fadda E, Fedeli U, Buja A, Lange JH. Lung cancer risk: effect of dairy farming and the consequence of removing that occupational exposure. Am J Epidemiol 2005; 161:1037-46.

165. Meyer A, Chrisman J, Moreira JC, Koifman S. Cancer mortality among agricultural workers from Serrana Region, state of Rio de Janeiro, Brazil. Environ Res 2003;93:264-71.

166. Morrison H, Savitz D, Semenciw R, Hulka B, Mao Y, Morison D, et al. Farming and prostate cancer mortality. Am J Epidemiol 1993:137:270-80.

167. Parker AS, Cerhan JR, Putnam SD, Cantor KP, Lynch CF. A cohort study of farming and risk of prostate cancer in Iowa. Epidemiology 1999;10:452-5.

168. Pukkala E, Martinsen JI, Lynge E, Gunnarsdottir HK, Sparén P, Tryggvadottir L, et al. Occupation and cancer - follow-up of 15 million people in five Nordic countries. Acta Oncol 2009; 48:646-790.

169. Rafnsson V. Cancer incidence among farmers exposed to lindane while sheep dipping. Scand J Work Environ Health 2006:32:185-9.

170. Sharma-Wagner S, Chokkalingam AP, Malker HS, Stone BJ, McLaughlin JK, Hsing AW. Occupation and prostate cancer risk in Sweden. J Occup Environ Med 2000;42:517-25.

171. Wesseling C, Ahlbom A, Antich D, Rodriguez AC, Castro R. Cancer in banana plantation workers in Costa Rica. Int J Epidemiol 1996;25:1125-31

172. Wigle DT, Semenciw RM, Wilkins K, Riedel D, Ritter L, Morrison HI, et al. Mortality study of Canadian male farm operators: non-Hodgkin's lymphoma mortality and agricultural practices in Saskatchewan. J Natl Cancer Inst 1990;82:575-82.

173. Wiklund K, Dich J. Cancer risks among male farmers in Sweden. Eur J Cancer Prev 1995:4:81-90.

174. Zeegers MP, Friesema IH, Goldbohm RA, van den Brandt PA. A prospective study of occupation and prostate cancer risk. J Occup Environ Med 2004:46:271-9.

175. Beane Freeman LE, Bonner MR, Blair A, Hoppin JA, Sandler DP, Lubin JH, et al. Cancer incidence among male pesticide applicators in the Agricultural Health Study cohort exposed to diazinon. Am J Epidemiol 2005;162:1070-9.

176. Christensen CH, Platz EA, Andreotti G, Blair A, Hoppin JA, Koutros $\mathrm{S}$, et al. Coumaphos exposure and incident cancer among male participants in the Agricultural Health Study (AHS). Environ Health Perspect 2010;118:92-6.

177. De Roos AJ, Blair A, Rusiecki JA, Hoppin JA, Svec M, Dosemeci $\mathrm{M}$, et al. Cancer incidence among glyphosate-exposed pesticide applicators in the Agricultural Health Study. Environ Health Perspect 2005;113:49-54

178. Greenburg DL, Rusiecki J, Koutros S, Dosemeci M, Patel R, Hines CJ, et al. Cancer incidence among pesticide applicators exposed to captan in the Agricultural Health Study. Cancer Causes Control 2008;19:1401-7.

179. Bonner MR, Lee WJ, Sandler DP, Hoppin JA, Dosemeci M, Alavanja MC. Occupational exposure to carbofuran and the incidence of cancer in the Agricultural Health Study. Environ Health Perspect 2005;113:285-9.

180. Lynch SM, Mahajan R, Beane Freeman LE, Hoppin JA, Alavanja MC. Cancer incidence among pesticide applicators exposed to butylate in the Agricultural Health Study (AHS). Environ Res 2009;109:860-8.
181. Mahajan R, Blair A, Coble J, Lynch CF, Hoppin JA, Sandler DP, et al. Carbaryl exposure and incident cancer in the Agricultural Health Study. Int J Cancer 2007;121:1799-805.

182. van Bemmel DM, Visvanathan $\mathrm{K}$, Beane Freeman LE, Coble J, Hoppin JA, Alavanja MC. S-ethyl-N,N-dipropylthiocarbamate exposure and cancer incidence among male pesticide applicators in the agricultural health study: a prospective cohort. Environ Health Perspect 2008;116:1541-6.

183. Hessel PA, Kalmes R, Smith TJ, Lau E, Mink PJ, Mandel J. A nested case-control study of prostate cancer and atrazine exposure. J Occup Environ Med 2004:46:379-85.

184. MacLennan PA, Delzell E, Sathiakumar N, Myers SL, Cheng H, Grizzle W, et al. Cancer incidence among triazine herbicide manufacturing workers. J Occup Environ Med 2002;44:1048-58.

185. Armstrong BG, Kazantzis G. Prostatic cancer and chronic respiratory and renal disease in British cadmium workers: a case control study. Br J Ind Med 1985:42:540-5.

186. Elghany NA, Schumacher MC, Slattery ML, West DW, Lee JS. Occupation, cadmium exposure, and prostate cancer. Epidemiology 1990;1:107-15.

187. Järup L, Bellander T, Hogstedt C, Spång G. Mortality and cancer incidence in Swedish battery workers exposed to cadmium and nickel. Occup Environ Med 1998;55:755-9.

188. Rooney C, Beral V, Maconochie N, Fraser P, Davies G. Case-control study of prostatic cancer in employees of the United Kingdom Atomic Energy Authority. BMJ 1993;307:1391-7.

189. Seidler A, Heiskel H, Bickeböller R, Elsner G. Association between diesel exposure at work and prostate cancer. Scand J Work Environ Health 1998;24:486-94.

190. Sorahan T, Esmen NA. Lung cancer mortality in UK nickel-cadmium battery workers, 1947-2000. Occup Environ Med 2004:61:108-16.

191. Decoufle P. Further analysis of cancer mortality patterns among workers exposed to cutting oil mists. J Natl Cancer Inst 1978:61:1025-30.

192. Järvholm B, Lavenius B. Mortality and cancer morbidity in workers exposed to cutting fluids. Arch Environ Health 1987;42: 361-6.

193. Krishnadasan A, Kennedy N, Zhao Y, Morgenstern H, Ritz B. Nested case-control study of occupational chemical exposures and prostate cancer in aerospace and radiation workers. Am J Ind Med 2007;50:383-90.

194. Ritz B. Cancer mortality among workers exposed to chemicals during uranium processing. J Occup Environ Med 1999;41: 556-66.

195. Tolbert PE, Eisen EA, Pothier LJ, Monson RR, Hallock MF, Smith TJ. Mortality studies of machining-fluid exposure in the automobile industry. II. Risks associated with specific fluid types. Scand J Work Environ Health 1992;18:351-60.

196. Blair A, Stewart PA, Zaebst DD, Pottern L, Zey JN, Bloom TF, et al. Mortality of industrial workers exposed to acrylonitrile. Scand J Work Environ Health 1998;24 Suppl 2:25-41

197. Marsh GM, Zimmerman SD. Mortality among chemical plant workers exposed to acrylonitrile: 2011 follow-up. J Occup Environ Med 2015:57:134-45.

198. Swaen GM, Bloemen LJ, Twisk J, Scheffers T, Slangen JJ, Collins $\mathrm{JJ}$, et al. Mortality update of workers exposed to acrylonitrile in The Netherlands. J Occup Environ Med 2004:46:691-8.

199. Symons JM, Kreckmann KH, Sakr CJ, Kaplan AM, Leonard RC. 
Mortality among workers exposed to acrylonitrile in fiber production: an update. J Occup Environ Med 2008;50:550-60.

200. Dragana A, John T, Michael S. Mortality experience of a cohort of rubber workers, 1964-1973. J Occup Med 1976;18:387-94.

201. Delzell E, Monson RR. Mortality among rubber workers. III. Cause-specific mortality, 1940-1978. J Occup Med 1981:23: 677-84.

202. Delzell E, Louik C, Lewis J, Monson RR. Mortality and cancer morbidity among workers in the rubber tire industry. Am J Ind Med 1981:2:209-16.

203. Delzell E, Sathiakumar N, Graff J, Macaluso M, Maldonado G, Matthews R. An updated study of mortality among North American synthetic rubber industry workers. Res Rep Health Eff Inst 2006;(132):1-63; discussion 65-74.

204. de Vocht F, Sobala W, Wilczynska U, Kromhout H, SzeszeniaDabrowska N, Peplonska B. Cancer mortality and occupational exposure to aromatic amines and inhalable aerosols in rubber tire manufacturing in Poland. Cancer Epidemiol 2009;33:94-102.

205. Gustavsson P, Hogstedt C, Holmberg B. Mortality and incidence of cancer among Swedish rubber workers, 1952-1981. Scand J Work Environ Health 1986;12:538-44.

206. McMichael AJ, Spirtas R, Kupper LL. An epidemiologic study of mortality within a cohort of rubber workers, 1964-72. J Occup Med 1974:16:458-64.

207. McMichael AJ, Andjelkovic DA, Tyroler HA. Cancer mortality among rubber workers: an epidemiologic study. Ann N Y Acad Sci 1976;271:125-37.

208. Monson RR, Fine LJ. Cancer mortality and morbidity among rubber workers. J Natl Cancer Inst 1978;61:1047-53.

209. Norseth T, Andersen A, Giltvedt J. Cancer incidence in the rubber industry in Norway. Scand J Work Environ Health 1983;9 Suppl 2:69-71.

210. Sorahan T, Parkes HG, Veys CA, Waterhouse JA, Straughan JK, Nutt A. Mortality in the British rubber industry 1946-85. Br J Ind Med 1989:46:1-10.

211. Szeszenia-Dabrowska N, Wilczyńska U, Kaczmarek T, Szymczak W. Cancer mortality among male workers in the Polish rubber industry. Pol J Occup Med Environ Health 1991:4:149-57.

212. Wingren G, Axelson $\mathrm{O}$. Cancer incidence and mortality in a Swedish rubber tire manufacturing plant. Am J Ind Med 2007:50:901-9.

213. Vlaanderen J, Taeger D, Wellman J, Keil U, Schüz J, Straif K. Extended cancer mortality follow-up of a German rubber industry cohort. J Occup Environ Med 2013;55:966-72.

214. Brown DA, Delzell E. Motor vehicle manufacturing and prostate cancer. Am J Ind Med 2000;38:59-70.

215. Jones MK, Harris MA, Peters PA, Tjepkema M, Demers PA. Prostate cancer and occupational exposure to whole-body vibration in a national population-based cohort study. Am J Ind Med 2014:57:896-905.

216. Järvholm B, Silverman D. Lung cancer in heavy equipment operators and truck drivers with diesel exhaust exposure in the construction industry. Occup Environ Med 2003;60:516-20.

217. Krstev S, Baris D, Stewart P, Dosemeci M, Swanson GM, Greenberg RS, et al. Occupational risk factors and prostate cancer in U.S. blacks and whites. Am J Ind Med 1998;34:421-30.

218. Nadalin V, Kreiger N, Parent ME, Salmoni A, Sass-Kortsak A, Siemiatycki J, et al. Prostate cancer and occupational wholebody vibration exposure. Ann Occup Hyg 2012;56:968-74.
219. Atkinson WD, Law DV, Bromley KJ, Inskip HM. Mortality of employees of the United Kingdom Atomic Energy Authority, 1946-97. Occup Environ Med 2004:61:577-85.

220. Boice JD, Cohen SS, Mumma MT, Dupree Ellis E, Eckerman KF, Leggett RW, et al. Mortality among radiation workers at Rocketdyne (Atomics International), 1948-1999. Radiat Res 2006;166(1 Pt 1):98-115.

221. Cardis E, Vrijheid M, Blettner M, Gilbert E, Hakama M, Hill C, et al. The 15-Country Collaborative Study of Cancer Risk among Radiation Workers in the Nuclear Industry: estimates of radiation-related cancer risks. Radiat Res 2007;164:396-416.

222. Checkoway H, Mathew RM, Shy CM, Watson JE Jr, Tankersley WG, Wolf SH, et al. Radiation, work experience, and cause specific mortality among workers at an energy research laboratory. Br J Ind Med 1985:42:525-33.

223. Gun RT, Parsons J, Crouch P, Ryan P, Hiller JE. Mortality and cancer incidence of Australian participants in the British nuclear tests in Australia. Occup Environ Med 2008;65:843-8.

224. Loomis DP, Wolf SH. Mortality of workers at a nuclear materials production plant at Oak Ridge, Tennessee, 1947-1990. Am J Ind Med 1996:29:131-41.

225. Muirhead CR, Bingham D, Haylock RG, O'Hagan JA, Goodill AA, Berridge GL, et al. Follow up of mortality and incidence of cancer 1952-98 in men from the UK who participated in the UK's atmospheric nuclear weapon tests and experimental programmes. Occup Environ Med 2003:60:165-72.

226. Samson E, Telle-Lamberton M, Caër-Lorho S, Bard D, Giraud JM, Metz-Flamant $\mathrm{C}$, et al. Cancer mortality among two different populations of French nuclear workers. Int Arch Occup Environ Health 2011;84:627-34.

227. Sigurdson AJ, Doody MM, Rao RS, Freedman DM, Alexander BH, Hauptmann M, et al. Cancer incidence in the US radiologic technologists health study, 1983-1998. Cancer 2003:97:3080-9.

228. Hughes MF, Beck BD, Chen Y, Lewis AS, Thomas DJ. Arsenic exposure and toxicology: a historical perspective. Toxicol Sci 2011;123:305-32.

229. International Agency for Research on Cancer (IARC). Occupational exposures in insecticide application, and some pesticides. IARC monographs on the carcinogenic risk to humans, No.53. Lyon, International Agency for Research on Cancer, 1991.

230. Diamanti-Kandarakis E, Bourguignon JP, Giudice LC, Hauser R, Prins GS, Soto AM, et al. Endocrine-disrupting chemicals: an Endocrine Society scientific statement. Endocr Rev 2009:30: 293-342.

231. Chauhan LK, Pant N, Gupta SK, Srivastava SP. Induction of chromosome aberrations, micronucleus formation and sperm abnormalities in mouse following carbofuran exposure. Mutat Res 2000;465:123-9.

232. Calderón-Segura ME, Gómez-Arroyo S, Molina-Alvarez B, Villalobos-Pietrini R, Calderón-Ezquerro C, Cortés-Eslava J, et al. Metabolic activation of herbicide products by Vicia faba detected in human peripheral lymphocytes using alkaline single cell gel electrophoresis. Toxicol In Vitro 2007;21:1143-54.

233. Gentile JM, Gentile GJ, Bultman J, Sechriest R, Wagner ED, Plewa MJ. An evaluation of the genotoxic properties of insecticides following plant and animal activation. Mutat Res 1982;101:19-29.

234. Nelson WG, De Marzo AM, Deweese TL, Lin X, Brooks JD, Putzi $\mathrm{MJ}$, et al. Preneoplastic prostate lesions: an opportunity for 
prostate cancer prevention. Ann N Y Acad Sci 2001;952:135-44.

235. Barry KH, Koutros S, Berndt SI, Andreotti G, Hoppin JA, Sandler $\mathrm{DP}$, et al. Genetic variation in base excision repair pathway genes, pesticide exposure, and prostate cancer risk. Environ Health Perspect 2011;119:1726-32.

236. Ekström G, Hemming H, Palmborg M. Swedish pesticide risk reduction 1981-1995: food residues, health hazard, and reported poisonings. Rev Environ Contam Toxicol 1996;147:119-47.

237. Swedish University of Agriculture. Use of pesticide. https://www.slu.se/en/Collaborative-Centres-and-Projects/centre-for-chemical-pesticides-ckb1/information-about-pesticidesin-the-environment-/overview-of-pesticides-and-their-use/. Accessed June 5, 2014.

238. International Agency for Research on Cancer (IARC). Chromium, nickel and welding. Lyon, International Agency for Research on Cancer, pp 49-214, 1990.

239. Costa G, Haus E, Stevens R. Shift work and cancer - considerations on rationale, mechanisms, and epidemiology. Scand J Work Environ Health 2010;36:163-79.

240. Markt SC, Flynn-Evans EE, Valdimarsdottir UA, Sigurdardottir LG, Tamimi RM, Batista JL, et al. Sleep duration and disruption and prostate cancer risk: a 23-year prospective study. Cancer Epidemiol Biomarkers Prev 2016;25:302-8.

241. Sigurdardottir LG, Markt SC, Rider JR, Haneuse S, Fall K, Schernhammer ES, et al. Urinary melatonin levels, sleep disruption, and risk of prostate cancer in elderly men. Eur Urol 2015;67:191-4

242. Papantoniou K, Pozo OJ, Espinosa A, Marcos J, Castaño-Vinyals G, Basagaña X, et al. Increased and mistimed sex hormone production in night shift workers. Cancer Epidemiol Biomarkers Prev 2015;24:854-63.

243. Rao D, Yu H, Bai Y, Zheng X, Xie L. Does night-shift work increase the risk of prostate cancer? A systematic review and meta-analysis. Onco Targets Ther 2015;8:2817-26.

244. Kubo T, Oyama I, Nakamura T, Kunimoto M, Kadowaki K, Otomo $\mathrm{H}$, et al. Industry-based retrospective cohort study of the risk of prostate cancer among rotating-shift workers. Int J Urol 2011;18:206-11.

245. Schwartzbaum J, Ahlbom A, Feychting M. Cohort study of cancer risk among male and female shift workers. Scand J Work Environ Health 2007;33:336-43.

246. Sigurdardottir LG, Valdimarsdottir UA, Fall K, Rider JR, Lockley SW, Schernhammer E, et al. Circadian disruption, sleep loss, and prostate cancer risk: a systematic review of epidemiologic studies. Cancer Epidemiol Biomarkers Prev 2012;21:1002-11.

247. Blettner M, Zeeb H, Auvinen A, Ballard TJ, Caldora M, Eliasch H, et al. Mortality from cancer and other causes among male airline cockpit crew in Europe. Int J Cancer 2003;106:946-52.

248. Blettner M, Zeeb H, Langner I, Hammer GP, Schafft T. Mortality from cancer and other causes among airline cabin attendants in Germany, 1960-1997. Am J Epidemiol 2002;156:556-65.

249. Paridou A, Velonakis E, Langner I, Zeeb H, Blettner M, Tzonou A. Mortality among pilots and cabin crew in Greece, 1960-1997. Int J Epidemiol 2003;32:244-7.

250. Ballard TJ, Lagorio S, De Santis M, De Angelis G, Santaquilani M, Caldora $\mathrm{M}$, et al. A retrospective cohort mortality study of Italian commercial airline cockpit crew and cabin attendants, 1965-96. Int J Occup Environ Health 2002;8:87-96.

251. Haldorsen T, Reitan JB, Tveten U. Cancer incidence among
Norwegian airline cabin attendants. Int J Epidemiol 2001;30: 825-30.

252. Hammar N, Linnersjö A, Alfredsson L, Dammström BG, Johansson M, Eliasch $\mathrm{H}$. Cancer incidence in airline and military pilots in Sweden 1961-1996. Aviat Space Environ Med 2002;73:2-7.

253. Pukkala E, Aspholm R, Auvinen A, Eliasch H, Gundestrup M, Haldorsen $\mathrm{T}$, et al. Incidence of cancer among Nordic airline pilots over five decades: occupational cohort study. BMJ 2002;325: 567.

254. Kushi LH, Doyle C, McCullough M, Rock CL, DemarkWahnefried W, Bandera EV, et al. American Cancer Society Guidelines on nutrition and physical activity for cancer prevention: reducing the risk of cancer with healthy food choices and physical activity. CA Cancer J Clin 2012;62:30-67.

255. Putnam SD, Cerhan JR, Parker AS, Bianchi GD, Wallace RB, Cantor KP, et al. Lifestyle and anthropometric risk factors for prostate cancer in a cohort of Iowa men. Ann Epidemiol 2000;10:361-9.

256. Thelin N, Holmberg S, Nettelbladt P, Thelin A. Mortality and morbidity among farmers, nonfarming rural men, and urban referents: a prospective population-based study. Int J Occup Environ Health 2009:15:21-8.

257. Decoufle P, Stanislawczyk K, Houten L, Bross ID, Viadana E. A retrospective survey of cancer in relation to occupation. Washington DC, US Department of Health, Education, and Welfare, National Institute for Occupational Safety and Health, 1977.

258. Williams RR, Stegens NL, Goldsmith JR. Associations of cancer site and type with occupation and industry from the Third National Cancer Survey Interview. J Natl Cancer Inst 1977:59:1147-85.

259. Acquavella J, Olsen G, Cole P, Ireland B, Kaneene J, Schuman S, et al. Cancer among farmers: a meta-analysis. Ann Epidemiol 1998;8:64-74.

260. International Agency for Research in Cancer (IARC). Cadmium and cadmium compounds. Lyon, IARC, pp 41-117, 1993.

261. Kiesselbach N, Korallus U, Lange HJ, Neiss A, Zwingers T. [Acrylonitrile--epidemiological study--Bay 1977: a report on a prospective epidemiological study with relapsed start by employees of the Leverkusen plant of Bayer AG with acrylonitrile (ACN) exposure]. Zentralbl Arbeitsmed Arbeitsschutz Prophyl Ergon 1979;29:256-9.

262. O'Berg MT. Epidemiologic study of workers exposed to acrylonitrile. J Occup Med 1980;22:245-52.

263. Thiess AM, Frentzel-Beyme R, Link R, Wild H. Mortality study with chemical technicians from various factories with exposure to acrylonitrile. Zentralbl Arbeitsmed Arbeitsschutz Prophyl Ergon 1980;30: 259-67.

264. Collins JJ, Page LC, Caporossi JC, Utidjian HM, Lucas LJ. Mortality patterns among employees exposed to acrylonitrile. J Occup Med 1989:31:368-71.

265. O'Berg MT, Chen JL, Burke CA, Walrath J, Pell S. Epidemiologic study of workers exposed to acrylonitrile: an update. J Occup Med 1985;27:835-40.

266. International Agency for Research on Cancer (IARC). Acrylonitrile. Lyon, IARC, pp 43-108, 1999.

267. Rothman KJ. Cancer occurrence among workers exposed to acrylonitrile. Scand J Work Environ Health 1994;20:313-21. 
268. International Agency for Research on Cancer (IARC). The rubber industry. IARC monographs on the evaluation of carcinogenic risk of chemicals to humans, 28. Lyon, IARC, 1982.

269. International Agency for Research on Cancer (IARC). Overall evaluations of carcinogenicity: an updating of IARC monographs volumes 1 to 42. IARC monographs on the evaluation of the carcinogenic risk of the chemicals to humans. Lyon, IARC, 1987.

270. Doll R. Hazards of ionising radiation: 100 years of observations on man. Br J Cancer 1995;72:1339-49.

271. International Agency for Research on Cancer (IARC). Ionizing radiation, part 1: $\mathrm{X}$ - and gamma $(\gamma)$-radiation, and neutrons. IARC monographs on the evaluation of carcinogenic risks to humans, No.75. Lyon, IARC, 2000.
272. International Agency for Research on Cancer (IARC). Radiation. A review of human carcinogens. IARC monographs on the evaluation of carcinogenic risks to humans, No. 100D. Lyon, IARC, 2012.

273. Boice JD. Ionizing radiation. In: Schottenfeld D, Fraumeni JF, eds. Cancer Epidemiology and Prevention. New York, Oxford University Press, pp 259-93, 2006.

274. Park ES, Moon K, Kim HN, Lee WJ, Jin YW. Radiation exposure and cancer mortality among nuclear power plant workers: a meta-analysis. J Prev Med Public Health 2010;43:185-92.

275. Thompson DE, Mabuchi K, Ron E, Soda M, Tokunaga M, Ochikubo S, et al. Cancer incidence in atomic bomb survivors. Part II: solid tumors, 1958-1987. Radiat Res 1994;137:S17-67. 